\title{
Herbs that heal: Relevance of traditional natural remedies in promotion of health
}

\section{Mohd. Kashif Husain *}

National Research Institute of Unani Medicine for Skin Disorders, Hyderabad-500038, India

\begin{tabular}{|c|c|}
\hline Article Info & Abstract \\
\hline $\begin{array}{l}\text { Keywords } \\
\text { Traditional medicine } \\
\text { Ethnobotany } \\
\text { Foenum vulgare Mill. } \\
\text { Trachyspermum ammi (L.) Sprague } \\
\text { Linum usitatissimum L. } \\
\text { Phytoconstituent } \\
\text { Pharmacology }\end{array}$ & $\begin{array}{l}\text { The age-old traditional healthcare practices have remained relevant for centuries and are being practiced } \\
\text { by communities all across the world. India's contribution to the development of traditional healthcare } \\
\text { systems continues to be exemplary. The current study reviews the strength of some common medicinal } \\
\text { plants and its useful parts; fruits/seeds, which are used in traditional healthcare systems and has been } \\
\text { contributing in promotion of health and longevity of indigenous people not only from time immemorial } \\
\text { but also making it tribal and rural people community's first choice for curing many chronic ailments. The } \\
\text { common household natural herbs have tremendous medicinal potential and are exploited by the existing } \\
\text { branches of traditional systems (AYUSH) to face the day-to-day challenges in the form of new diseases } \\
\text { (pandemic/endemic). The significant role of plants as a source raw material for making different } \\
\text { formulations used in AYUSH-systems of medicine is well established. An extensive literature survey was } \\
\text { undertaken for compilation of information on one of the famous traditional systems of medicine in India, } \\
\text { i.e., Unani, which is a holistic system of treatment, is based on the blending of the use of medicine, regular } \\
\text { food (diet), and adhering to basic physical activities (exercise) and behaviour. The common medicinal } \\
\text { herbs provide a more practical, productive as well as an accessible source of medicine. The present review } \\
\text { describes the ethnobotanical relevance, medicinal benefits, phytoconstituents and pharmacological activities } \\
\text { of fennel/sounf (Foenum vulgare) fruits, ajwayin/ajowan (Trachyspermum ammi) fruits and alsi/flaxseed } \\
\text { (Linum usitatissimum). These three herbs are not only commonly available but are full of essential } \\
\text { nutrients, vitamins, minerals, amino acids, and phytoconstituents; tannins, polyphenols, terpenoids and } \\
\text { many more, that promote overall health, rejuvenates the body, age associated disorders and boosts the } \\
\text { immunity to fight against the communicable, and non-communicable diseases (NCD). This article explains } \\
\text { the scientific basis for the use of these herbs therapeutically to deal with a variety of ailments as well as } \\
\text { to preserve overall health. }\end{array}$ \\
\hline
\end{tabular}

\section{Introduction}

India is one of the twelve mega-biodiversity countries of the world, having rich vegetation with a diverse range of plants with high medicinal values. It is estimated that more than 6,500 plant species are known to exist in India and are used by different streams of traditional healthcare practitioners. India is also an inhabitant of oldest, richest and most diverse cultured traditions associated with the use of medicinal plants in the form of traditional systems of medicine (Husain et al., 2016). The plant based systems of medicine continue to provide the needs of primary healthcare since thousands of years. The ancient civilization relied heavily on botanical sources of medicine. Plant materials are still used by more than $80 \%$ of the world population in developing and underdeveloped countries. Many assertions concerning the efficacy of modern medications have been proven to be true; it's worth noting that the majority of them are derived from plants. Plant-based herbal remedies are considered to be safe as they are obtained from natural resources.

\section{Corresponding author: Dr. Mohd Kashif Husain} Scientist, Survey of Medicinal Plant Unit, National Research Institute of Unani Medicine for Skin Disorders, Hyderabad-500038, T.S., India E-mail: kashifptc@gmail.com

Tel.: +91-7382189745

Copyright () 2021 Ukaaz Publications. All rights reserved.

Email: ukaaz@yahoo.com; Website: www.ukaazpublications.com
Based on the traditional knowledge and experience, many local and indigenous communities in the developing Asian countries still meet their basic needs from the medicinal plant products, which they manufacture for their livelihood. The major populations of the tribal and rural people, who are residing in completely remote areas, are more or less dependent on the forest products especially on the medicinal plants. The ethnomedicines procured from the medicinal plants are believed to be much safer; and has proved its efficacy in the treatment of multiple diseases (Mitalaya et al., 2003).

The tribal communities which live close to the nature, has acquired the indigenous knowledge to use the medicinal plants against different disease conditions (Husain et al., 2015). In India, nearly 705 different tribal communities are present and they are largely depends on ethnomedicine. The interest in traditional knowledge on ethnomedicine has continuously been increasing; recently, various ethnobotanical studies have been explored and the documentation of knowledge from the different tribal communities of Andhra Pradesh, Telangana and other regions has been reported in detailed by many workers (Husain et al., 2016).

The modern system of medicines is based on the active pharmaceutical ingredient. But, during the preparation of a drug, other excipients like; disintegrators, binders, fillers, flavors, colors and preservatives are also added that may cause the adverse side effects. The healer components themselves are fast transforming into ailments causative agents. 
Traditional medicines have been used since thousands of years to maintain and cure the day-to-day health related issues. The World Health Organization (WHO) defined the traditional medicine as "the sum total of all the knowledge and practices, whether explicable or not, used in diagnosis, prevention and elimination of physical, mental or social imbalance and relying exclusively on practical experience and observations handed down from generation to generation, whether verbally or in writing". Access to "modem" healthcare services and medicine may be limited in developing countries. Plant based traditional medicines becomes the only affordable treatment available to deprived people and in remote communities. Healthcare providers worldwide including major pharmaceutical giants are turning to incorporate many of these into their mainstream activities (Husain et al., 2017).

World Health Organization (WHO) has acknowledged that a large population of the world treats itself using plant based natural medicines. Considering the fact, WHO has launched the traditional medicine strategy (2014-2023), with an aim to keep the world population healthy by prioritizing the use of traditional/ complementary medicine. Modern scientific tools give a logical understanding for the use of medicinal herbs for the prevention and treatment of common illnesses. Traditional medicine is now been accepted worldwide not only for cure but also for well-being.

Indian Systems of Medicine (AYUSH-Ayurveda, Unani, and Siddha) have been used for hundreds of years for healing and preventative healthcare all over the world. Ayurveda is the oldest system with well documented history of its practice since more than five thousand years, whereas, the Unani (Greco-Arab) System of medicine, which originated in Greece and gone through many countries to established itself in India during the medieval period. It is based on wellestablished knowledge and practices relating to the promotion of positive health and prevention of disease (Husain et al., 2017). The Unani healthcare system is one of the recognized medicinal practice of India that is holistic in nature and is based on the adaptation of the human body to the environment (Khan, 2006). The fusion of traditional knowledge of ancient civilizations like Egypt, Arabia, Iran, China, Syria and India, these systems are being practised in the country with diverse preferences of people and infrastructural facilities. The medicine of Chinese system helped in supportive and palliative care by lower down the side-effects of conventional treatment of deadly disease like cancer or improving the (QoL) quality of life (Ernst, 2009). It is estimated the United States National Cancer Institute (NCI) spends around $\$ 120$ million each year on Complementary and Alternative Medicine (CAM) related research projects (Jia, 2012). TCM has increasingly become popular in the West including in cancer patients (Boon et al., 2007) plays an important role in minimizing disability, protecting patients against suffering from complications, and helping patients to live well (Yoder, 2005).

Considering the importance of the traditional medicine and herbs the current review article has been conceptualized on three important plants; fennel (Foeniculum vulgare), ajwayin (Trachyspermum ammi) and alsi (Linum usitatissimum) on the basis of botany, their therapeutic uses, phytoconstituents and pharmacological activities.

\section{Fennel : Foeniculum vulgare Mill.}

Commonly known as sounf, madhurika (Ayurved) and baadiyaan (Unani), belongs to Apiaceae.

\subsection{Botanical description}

An erect, hardy, aromatic, perennial herb of 1-2 m height, alternate leaves, 3-4 times pinnate, decompound; petioles ca. 5.5-15 cm; lamina 4-30 $\times 5-40 \mathrm{~cm}$, broadly triangular in outline, 4-5-pinnatisect; ultimate segments linear. Superior leaves are with sheaths larger than the blade. Flower petals yellow in compound umbels (JuneOctober), stamens much longer than petals. Fruits are greenish or yellowish, ca. $0.6 \mathrm{~cm}$ long and $0.2 \mathrm{~mm}$ in diameter, oblong or ellipsoid, glabrous, concave, ridged, aromatic, oblong, semi cylindrical, with 5 prominent ribs, sweet and pungent in taste.

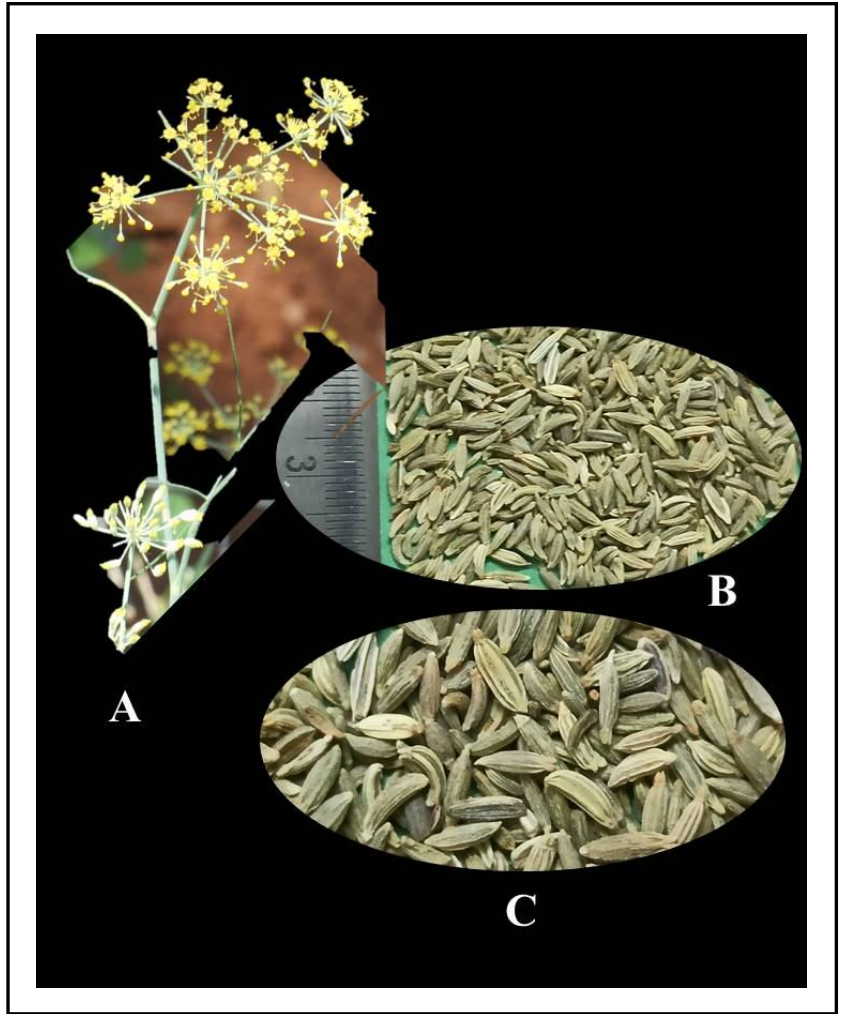

Figure 1: 1A. Fennel inflorescence 1B-C fennel (F. vulgare) fruits.

\subsection{Parts used}

Fruits/seeds, oil and root.

\subsection{Historical background}

The history of the fennel dates back to the ancient times. It is one of the most prominent herbs throughout the world and universally known as fennel. It is native to the Mediterranean region, and is presently cultivated in calm areas around the globe. It has more than hundred other names. It has been used medicinally all over the world since very old times (Andrew, 2016; Badgujar et al., 2014). Hippocrates and Dioscorides mentioned fennel as diuretic and emmenagogue, and the juice was supposed to sharpen the eyesight (Dymock et al., 1972). Dioscorides, in the 1st century CE, expresses that 'the juice' when put into the eye, helps vision, and into the ear, it kills the worm (Andrew, 2016).

\subsection{Therapeutic actions and uses}

In Europe and Mediterranean regions, the fennel is traditionally used as anti-inflammatory, analgesic, antispasmodic, as eye lotion, 
diuretic, galactagogue, secretomotor, secretolytic, and antioxidant remedy and integrator; topically application of the fennel powder is used as a poultice to treat snakebites (Gori et al., 2012). In India, water made from fennel fruit is used to relieve the colic pain, flatulence and a hot infusion is used to improve lactation and to treat amenorrhea (Nadkarni, 1954). It is also used as a diaphoretic and diuretic and in infants and children (Khory and Katrak, 1984). Fennel (saunf) is one of the most regularly quoted herb in 'The Chilandar Medical Codex', the finest preserved medieval Serbian classical literature on European medical science from $12^{\text {th }}$ to $15^{\text {th }}$ Centuries (Jariæ et al., 2011). Fruits (seeds) are carminative and stomachic, emmenagogue (Keys, 1985; Saha and Kashinathan, 1961), especially reputed to promote menstruation, facilitate birth, increase milk secretion, alleviate symptoms of the male climacteric, and increase libido (Albert-Puleo, 1980; Breyer-Brandwijk and Watt, 1962).

In Unani system of medicine, the temperament (Mizaj) of fennel is hot $2^{\circ}$ and dry $1^{\circ}$. It is carminative (Kasir-i-Riyah), concoctive of phlegm and black bile (Mundij-i-Balgham wa Sawda'), galactopoietics (Muwallid-i-Laban), deobstruent (Mufatteh Sudad), analgesic (Dafae dard), galactogogue (Mudirr-i-Laban) and diurectic (Mudirr-i-Bawl). Fennel (Badiyan) is used to remove liver and spleen obstructions, relieve flatulent colic, and induce diuresis and menstruation (Hakeem, 2002; Ghani, 1920).

\subsection{Ethnobotanical uses}

Fennel plant (whole) and its part; root, stem, fruit, leaves, seeds, are medicinally used in different forms for the treatment of a number of diseased conditions. The methods of preparation, uses, and its application are well documented in the common ethnobotanical literature. The plant is ethnomedicinally used to treat abdominal pains, arthritis, as antiemetic, aperitif, constipation, flatulence, laxative, colic in children, irritable colon, conjunctivitis, depurative, diarrhoea, dieresis, emmenagogue, fever, gastralgia, gastritis, headache, insomnia, kidney ailments, menstrual irregularty, leucorrhoea, liver pain, mouth ulcer, mouth pain and stomachache.
In addition to its ethnomedicinal uses, the fruit/seed of fennel are extensively used as galactagogue not only to increase the quality and quantity of the milk but also to improve the flow of milk of lactating mothers (Guarrera and Savo, 2013; Badgujar et al., 2014). Some important information on ethnomedicinal uses has been summarized in Table 1.

A survey of the available ethnobotanical literature on $F$. vulgare showed that most of the workers have reported that all plant parts are employed for the treatment of different diseases, but fruits/ seeds are the most commonly utilized plant part with $46 \%$ utilization followed by leaves $(37 \%)$, roots $(6 \%)$, whole plant $(6 \%)$ and the (5\%) flowers (Figure 2).

Majority of the claims were recorded in the form of decoction followed by infusion (Figure 3). Most of the workers reported its ethnomedicinal use on disease conditions like gastric and intestinal diseases (maximum-21), followed by oral and dental diseases (7), cough, cold, bronchitis (6), urologic diseases (5), skin infections (4), hypertension (2), hypercholesterolemia (2) back pain (1), conjunctivitis (1), headache (1) and haemorrhoid (1) (Figure 4).

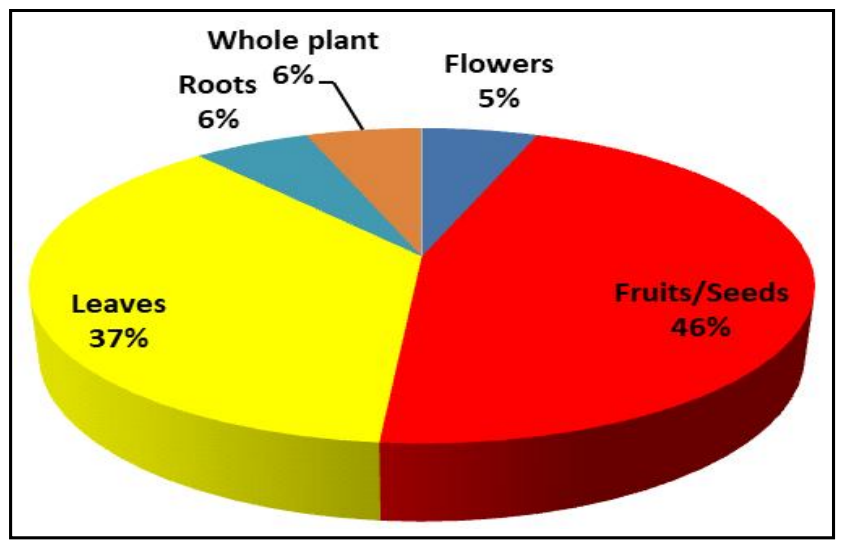

Figure 2: Usage of fennel $(F$. vulgare $)$ plant part.

Table 1: Ethnomedicinal uses of fennel ( $F$. vulgare)

\begin{tabular}{|c|c|c|c|c|}
\hline S. No. & Plant part used & Form of ethnomedicine & Ethnomedicinal uses and therapeutics & Reference \\
\hline 1. & Leaves, fruits & Decoction, pounded & Itchy, urticaria/hives, cough, motion sickness & Jadid et al., 2020 \\
\hline 2. & $\begin{array}{l}\text { Leaves, fruits, roots, } \\
\text { aerial parts }\end{array}$ & $\begin{array}{l}\text { Decoction, hydro distillation, } \\
\text { infusion, powder/oral }\end{array}$ & $\begin{array}{l}\text { Relieve abdominal pain, back pain, joint pain, } \\
\text { low back pain, colic pain, dental pain, menstrual } \\
\text { pain, post-delivery pains, cough, asthma, } \\
\text { bronchitis, diarrhea, gastritis and reflex; as } \\
\text { appetizer, carminative, sedative, diuretic, } \\
\text { digestive; to remove gallstones and urinary tract } \\
\text { stones, to cure gout, hemorrhoid, bloating, } \\
\text { kidney infectionsand parasitic infection; to } \\
\text { increase lactation in nursing mothers and to } \\
\text { stimulate menstruation (in amenorrhea) }\end{array}$ & $\begin{array}{l}\text { Moazzami et al., } \\
2018\end{array}$ \\
\hline 3. & Fruits & Decoction & Hypertension & Malik et al., 2018 \\
\hline 4. & $\begin{array}{l}\text { Leaves along with } \\
\text { the seeds }\end{array}$ & $\begin{array}{l}\text { Boiled in coconut oil (Cocos } \\
\text { nucifera) and the oil extract } \\
\text { is applied on the head daily } \\
\text { in the morning hours for a } \\
\text { week }\end{array}$ & Dandruff & $\begin{array}{l}\text { Singh and Singh, } \\
2009\end{array}$ \\
\hline 5. & Fruits & Decoction gargle & Mouth care & Najem et al., 2020 \\
\hline
\end{tabular}




\begin{tabular}{|c|c|c|c|c|}
\hline 6. & Fruits & Powder (one tablespoon) & $\begin{array}{l}\text { Acute ache; digestion problems; intestinal } \\
\text { comfort; bloating }\end{array}$ & $\begin{array}{l}\text { Es-Safi et al., } \\
2020\end{array}$ \\
\hline 7. & Fresh leaves, fruits & Decoction, infusion, smoke & Headache, carminative, toothache & Mautone et al., 2019 \\
\hline 8. & Tender leaves & Chewed and stuck on ulcer & Mouth ulcer & Guarrera et al., 2005 \\
\hline 9. & Fruit and seed & $\begin{array}{l}\text { Decoction is used as mouth } \\
\text { wash }\end{array}$ & Gum disorder & Jaric et al., 2007 \\
\hline 10. & Leaf & Infusion & Insomnia & Oliveira et al., 2012 \\
\hline 11. & Seeds & Decoction & Constipation & Jaric et al., 2011 \\
\hline 12. & $\begin{array}{l}\text { Seeds mixed with } \\
\text { sugar }\end{array}$ & Chewed & Constipation & Kumar et al., 2009 \\
\hline 13. & Leaf, flower & Aqueous infusion & Conjunctivitis, gastritis & Tene et al., 2007 \\
\hline 14. & Root, seeds & Decoction & Diuresis & $\begin{array}{l}\text { Halberstein et al., } \\
2012\end{array}$ \\
\hline 15. & $\begin{array}{l}\text { Whole plant, fruits } \\
\text { and floral tops }\end{array}$ & Decoction & Abdominal pain, cold & Savo et al., 2011 \\
\hline 16. & Leaf, seeds & Infusion & Abdominal pain, irritable colon & Alzweiri et al., 2011 \\
\hline 17. & Leaves & Chewed & Abdominal pain & Bulut et al., 2013 \\
\hline 18. & Leaves & Decoction with a little honey & Swollen stomach & Guarrera et al., 2005 \\
\hline 19. & Leaves & Chewed & Antihypertensive and anticholesterolemic & Carrio et al., 2012 \\
\hline 20. & Leaf and fruit & Infusion & Colic in children & $\begin{array}{l}\text { Albuquerque et al., } \\
2007\end{array}$ \\
\hline
\end{tabular}

\subsection{Phytoconstituents}

Phytochemical research carried out on different parts of fennel $(F$. vulgare) has led to the isolation of volatile components, phenolic components, fatty acids, hydrocarbons, and few other classes of secondary metabolites. Fennel is also reported as one of the highest plant sources of sodium $(\mathrm{Na})$, potassium $(\mathrm{K})$, phosphorus $(\mathrm{P})$, and calcium (Ca) (Badgujar et al., 2014). Elements like Fe, Mn, Ca, Mg, $\mathrm{Cu}, \mathrm{Cr}, \mathrm{Co}, \mathrm{Zn}, \mathrm{Ni}$, and $\mathrm{Cd}$ are also reported to be present in fennel fruits (Endalamaw et al., 2015).

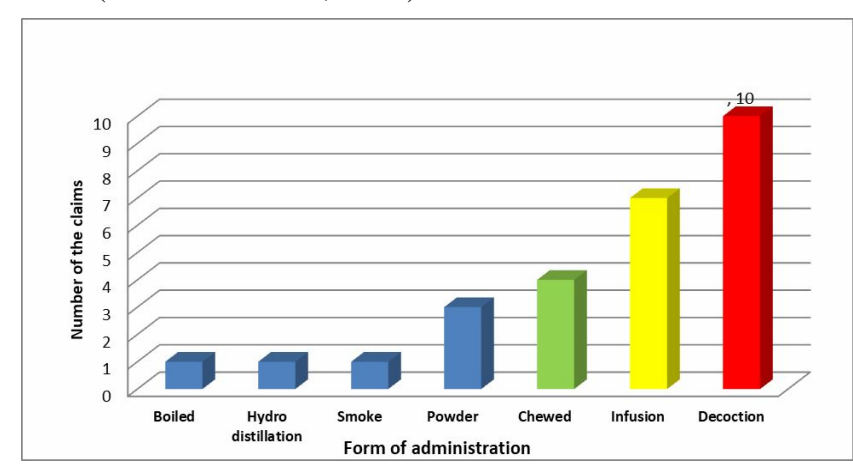

Figure 3: Form of administration.

\subsubsection{Essential oil (EO)}

Most of the phytochemicals are found in essential oil (EO). The EO content is responsible for anise flavour of fennel. The accumulation of the volatile compounds inside the fennel plant is found in different parts like; roots, stem, shoots, flowers, and fruits (D'iaz-Maroto et al., 2006; Gross et al., 2009). Some of the phytoconstituents of fennel is useful as coloring and antiageing agents (Grae, 1974; Rasul, 2012). The odor of fennel makes an excellent flavoring agent in diffrenet types of food and food related products. The EO of fennel has been reported to comprise more than 87 types of volatile compounds (Akgul and Bayrak, 1988; Telci et al., 2009; Zoubiri et al., 2010).

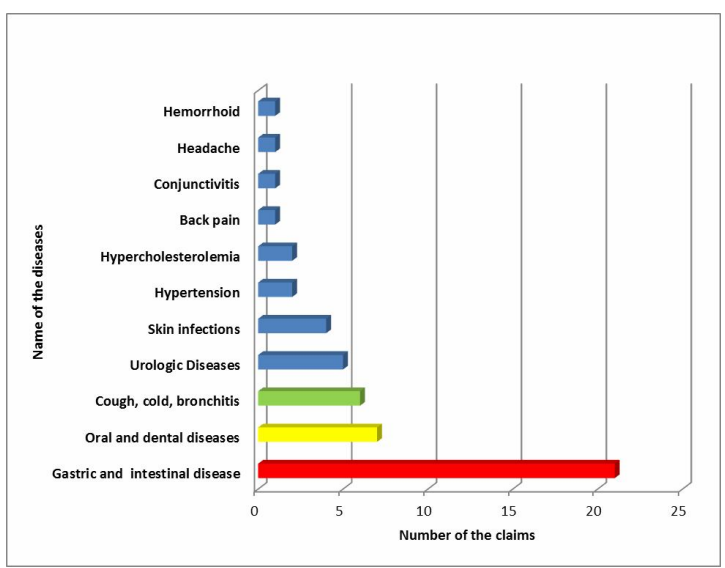

Figure 4: Ethnomedicinal uses of fennel $(F$. vulgare $)$ in different disease conditions.

The method of distillation notably affects the quantitative composition and yield of $F$. vulgare EO. Generally, the fennel oil extracted either by supercritical fluid extraction or distillation extraction methods, it shows transanethole, fenchone and estragole as the main components (Díaz-Maroto et al., 2005). The predominant constituent of the EO is transanethole (85.6\%) (DíazMaroto et al., 2006;), followed by estragole in small amounts (2.8\%), and less than $1 \%$ fenchone (Cooge et al., 2008). Methyl chavicol 
(estragole) reported to be the dominant constituent in the fruit EO, and limonene $\alpha$-pinene and transanethole, being the main components of the EO obtained from the dried aerial parts (Miguel et al., 2010). While EO from fruits of Portugal showed maximum (47\%- E-anetol), followed by (11\%- $\alpha$-phellandrene), (10\% $\alpha$ pinene) and $10.8 \%$ fenchone) as the main constituents (Cabral et al., 2017).

\subsubsection{Flavonoids}

The flavonoids, an important category of antioxidants are found in abundance in the plants of Apiaceae, and are generally useful for the human diet. The presence of flavonol glycosides in fennel is depending upon its morphological heterogeneity and variation found in different agroclimatic regions. The most prevalent flavonoids are; isoquercitrin, quercetin-3-arabinoside, quercetin-3-glucuronide, isorhamnetin glucoside, kaempferol-3- arabinoside and kaempferol3-glucuronide (Kunzemann and Herrmann, 1977). While, kaempferol-3-O-glucoside, quercetin-3-O-galactoside, kaempferol3-O-rutinoside, have also been reported to be found in the aqueous extract of fennel (Parejo et al., 2004; Guillen and Manzanos, 1996).

\subsubsection{Phenols}

The phenolic components present in fennel ( $F$. vulgare) are considered to be associated with the prevention of diseases caused by oxidative stress. The aqueous extracts of fennel fruits are rich in phenols which exhibited antioxidant and hepatoprotective properties (Ghanem et al., 2012). These phenolic compounds have received tremendous attention among nutrition biologist, scientists, and the common people due to their role in human health. F. vulgare contains hydroxyl cinnamic acid derivatives (Parejo et al., 2004). The fennel fruits methanolic extract have rosmarinic acid (14.9\%) and chlorogenic acids $(6.8 \%)$ as the major phenolic compounds. Phenolic acids like; 5-O-caffeoylquinic acid, 4-O-caffeoylquinic acid, 3-O-caffeoylquinic acid, 1,5-O-di-caffeoylquinic acid, 1,4-Odicaffeoylquinic acid and 1,3-O-di-caffeoylquinic acid are reported to be present in fennel (Faudale, 2008).

\subsection{Pharmacological actions}

A number of studies showed that fennel plant possessed broad pharmacological properties including; anti-inflammatory, antioxidant, anticancer, antihyperuricemic hepatoprotective, antibacterial activity, and anti-fungal.

\subsubsection{Antibacterial and antifungal activity}

A significant antibacterial activity of acetone and hot water extracts of fennel have been reported against E. coli, E. faecalis, S. typhi, S. typhimurium, S. aureus, and P. aeruginosa (Kaur and Arora, 2009). The essential oil (EO) obtained from the fennel found to be effective against the various strains of $S$. aureus, E. coli, S. enterica, B. cereus (Lixandru et al., 2010). EO also showed significant antifungal activity against $C$. albicans (Pai et al., 2010) and toxigenic Aspergillus species. Th EO reported to exhibited the potent activity against dermatophytes like; T. tonsurans, T. rubrum, T. mentagrophytes and M. gypseum. The activity reported to be better than the two antifungal agents; amphotericin B and fluconazole (Zeng et al., 2015).

\subsubsection{Anti-inflammatory activity}

The methanolic extract of fennel (F. vulgare) fruit showed inhibitory effects against acute and subacute inflammatory diseases and type
IV allergic reactions. It also showed a central analgesic effect. The finding supported the use of fruit in relieving inflammation (Choi and Hwang, 2004).

\subsubsection{Anxiolytic activity}

The ethanolic extracts of fennel fruit exhibited anxiolytic activity which was validated by elevated plus maze, rota rod, open field test, and hole board models. The standard drug diazepam $(1 \mathrm{mg} / \mathrm{kg})$ was compared to assess the efficacy of the extract (100-200 mg/ $\mathrm{kg}$ ). The ethanolic extract of fruit showed anxiolytic activity and provide a scientific evidence for its traditional claim (Kishore et al., 2012).

\subsubsection{Diuretic activity}

Diuresis helps the expulsion of urine (urine volume) and urinary sodium from the body to help to reduce the volume of blood circulating through the cardiovascular system. The ethanolic extract of fennel fruit exhibited excellent diuretic activity and validated proves the earlier folk claim. The fruit extract exhibited a highly significant diuretic effect in mice which was found to be comparable with urea with a urine output that was almost double that of the control group without changing the sodium and/or potassium level excretion (Tanira et al., 1996).

\subsubsection{Estrogenic activity}

The acetone extract of fennel fruit exhibited the estrogenic activity; increased the weight of mammary glands, oestrus cycle in female rats and vaginal cornification (Malini et al., 1985). The EO of fennel exhibited estrogenic activity; promoted menstruation and alleviated the symptoms of female climacteric with increased libido (Albert-Puleo, 1980). The oil (10, 20 and $4050 \mu \mathrm{g} / \mathrm{ml})$ obtained from the $F$. vulgare (fennel) fruits significantly reduced the frequency of uterine contraction induced by prostaglandin E2 (Ostad et al., 2001).

\subsubsection{Hepatoprotective activity}

The oral administration of essential oil from the fruits of fennel exhibited a potent hepatoprotective effect against acute hepatotoxicity induced by $\mathrm{CCl}_{4}$ (carbon tetrachloride) in rats. The level of bilirubin, alkaline phosphatase (ALP), serum aspartate aminotransferase (AST) and alanine aminotransferase (ALT) found to be decreased as compared to the control group. The EO constituents (d-limonene and $50 \beta$-myrcene) may have played an important key role in the protection of liver against $\mathrm{CCl}_{4}$ - induced hepatic damage in animal (Ozbek et al., 2003).

\subsubsection{Other pharmacological activities}

Fennel (F. vulgare) supplemented diet protected the rats against cyclosporine induced nephrotoxicity (Shalby et al., 2012). Methanol extract of fruit exhibited inhibitory effects against acute and subacute inflammation and also exhibited a central analgesic effect. It also significantly increased HDL-C level and plasma antioxidant enzymes activities (Choi and Hwang et al., 2004).

Aqueous extract of fennel fruit increased the gastric acid secretion in rats by more than three times, without blocked by atropine; and significantly reduced the basal acid secretion in aspirin-induced gastric mucosal damage in rats (Vasudevan et al., 2000). Oral administration of EO and anethole also significantly protected against ethanol-induced gastric lesions in rats. Fennel fruit extract 
significantly inhibited the generation of ROS from $H$. pylori-infected gastric epithelial cells. Infusion of aerial parts showed better in vitro antioxidant activity (Guimarães et al., 2011; Zaidi et al., 2012).

EO and ethanolic extract obtained from the fruit significantly produced in vitro relaxant effect on methacholine-induced contraction of tracheal chain, while calcium channels inhibition was not a contributing mechanism of the relaxant effect (Boskabady et al., 2004). Pre-treatment with aqueous extract significantly reduced the ethanol-induced gastric damage in rats (Tognolini et al., 2007, Birdane et al., 2007). The coumarins isolated from the fruits showed excellent in vitro antioxidant activities (Yang et al., 2015). Fruit extract also exhibited the in vitro immune-modulatory NF kappa B activities (Kaileh et al., 2007).

\section{Ajwayin: Trachyspermum ammi (L.) Sprague}

Commonly known as ajowan/ajwayin, yavaani (Ayurved) and nankhwah (Unani), belongs to Apiaceae family.

\subsection{Botanical description}

The plant is native to India (mainly Gujarat and Rajasthan), Mediterranean countries, and Iran. Erect annual, $15-50 \mathrm{~cm}$ tall, branched. Profusely branched annual herb, $15-50 \mathrm{~cm}$ tall, stem glabrous, striate. Leaves much divided; ultimate segments filiform.; inflorescence compound umbel. Umbellules 20 flowered. Flowers; white, male and bisexual; 5 corolla having petals bilobed; 5 stamens, alternating with the petals; ovary inferior; stigma knob-like; fruit ovoid, cordate, cremocarp (with a persistent stylopodium) ; ridges not prominent. Flower, Fruit : November-April.

The oval-shaped very small fruits, often referred to as seeds, resemble caraway and cumin fruits, are pale-brown in color with a bitter and pungent taste, and a flavor similar to anise and oregano. The surface is highly tubercled, marked with prominent ridges (five or ten), the intervening spaces dark brown; on bruising the odor is strong.

\subsection{Parts used}

Fruits/seeds, root, leaves and oil.

\subsection{Historical background}

Dioscorides described it as a small African seed (ammi), having odor like origanon (origanum). He mentioned it as a very hot and dry in nature and carminative. Avicenna described it as Nankhwah, and Pliny mentioned that ammi and King's cumin are identical (Dymock, 1972). Many scholars also identified nankhwah with the ammi of Dioscorides. T. ammi, though smell like thyme, but is more aromatic, and less subtle in taste. A small number of fruits tend to give flavour of a dish.

\subsection{Therapeutic actions and uses}

The ajwayin is known for its antiseptic properties. It is used to promote healing of foul sores, and to remove odor of the discharges from them (Dymock, 1972). Galen described ajwain as diuretic and anti-inflammatory. Dioscorides also mentioned it as diuretic and emmenagogue. Tabri stated that ajwayin 'cleanse' the urinary tract and expels the renal stones (Ibn al-Baitar, 2003).

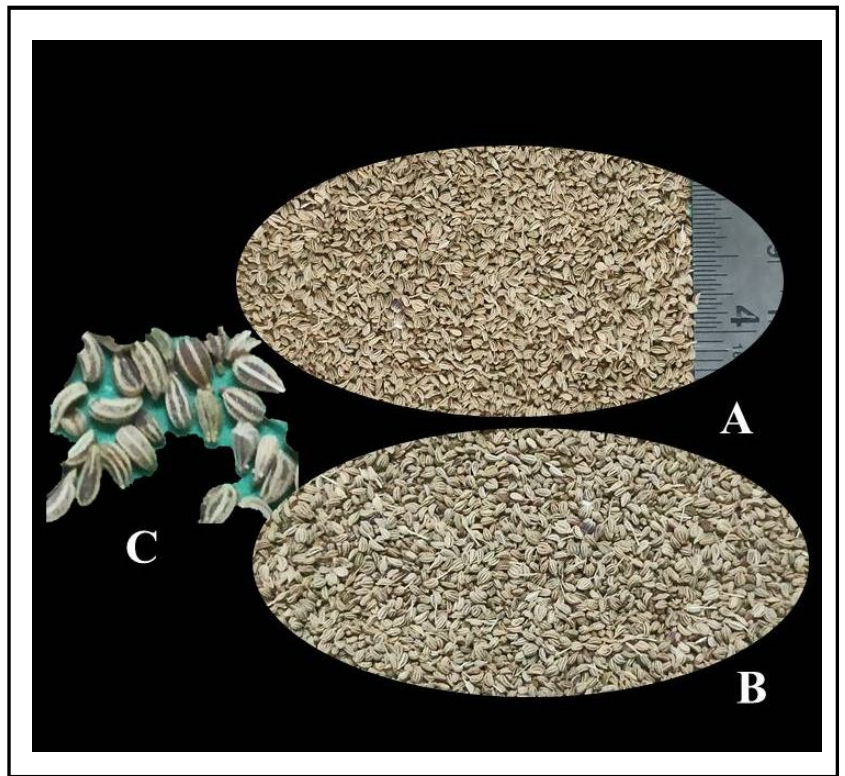

Figure 6: 6A-B. Ajwayin (T. ammi) fruits, 6C. Ajwayin fruits (enlarged view).

Being stomachic, ajwayin fruits increases the flow of saliva, and stimulate the gastric secretions. It is used in the treatment of flatulency, intestinal colic, atonic dyspepsia, heartburn, eructations, and diarrhoea. A poultice made up of crushed the fruits is applied externally to treat painful rheumatic joints and hot fomentation to the chest in bronchitis and asthma (Kirtikar and Basu, 1996; Keys, 1985). In Indian system of traditional medicines, the fruits are used for the treatment of bronchial asthma and piles. It is used to treat amenorrhea and as galactagogue (Bairwa et al., 2012). Ajwayin is used as a carminative, either alone or in combination with rock salt, asafoetida, or myrobalan. It checks chronic discharges, and is prescribed in bronchitis with copious expectorations, and to make lotions and collyria. A plaster or poultice of crushed seeds (fruits) relieves pain (Dymock et al., 1972). While, in Iran, traditionally, ajwayin fruits are used for the treatment of joint pains and headache (Dashti-Rahmatabadi et al., 2007).

As per the classical text, Unani physicians of India consider the fruits/seeds as, hot $3^{\circ}$ and dry $3^{\circ}$ temperament, appetizer, anthelmintic, analgesic, antiseptic, antidote carminative, deobstruent, diuretic, drying, detergent, emmenagogue, rubefacient, resolvent and spamsmolytic. Ajwayin is used in the treatment of flatulence, stomachache, loss of appetite, chronic fevers, ascites, whooping cough, liver and spleen inflammations hardness, and in epidemic diseases (Kabeeruddin, 1937). Among over-the-counter drugs of Unani medicine, Majoon-e-Naankhwaah (Bayaz-e-kabir) is prescribed in flatulence and anorexia; Araq-e-Ajawaayin as a carminative. The famous Unani medicine-'Araq-e- Ajeeb' consist of sublimated ajawayin and pudinaa (Mentha arvensis). It is prescribed for dyspepsia, nausea, vomiting, diarrhoea, and cholera (Khare, 2004).

\subsection{Ethnobotanical uses}

In folk medicine, Ajawaayin is used in conjunction with rock salt or black salt, asafoetida and myrobalans. Taken with buttermilk, ajawayin is a common remedy for relieving difficult expectoration 
due to dried-up phlegm (Khare, 2004). Some important information on ethnomedicinal uses has been summarized in Table 2 .

A survey of the available ethnobotanical literature on $T$. ammi showed that most of the workers have reported that all plant parts are employed for the treatment of different diseases but fruits/ seeds are the most commonly utilized plant part with $80 \%$ utilization fallowed by roots (8\%), leaves (4\%), whole plant (4\%) and $(4 \%)$ flowers (Figure 7 ).

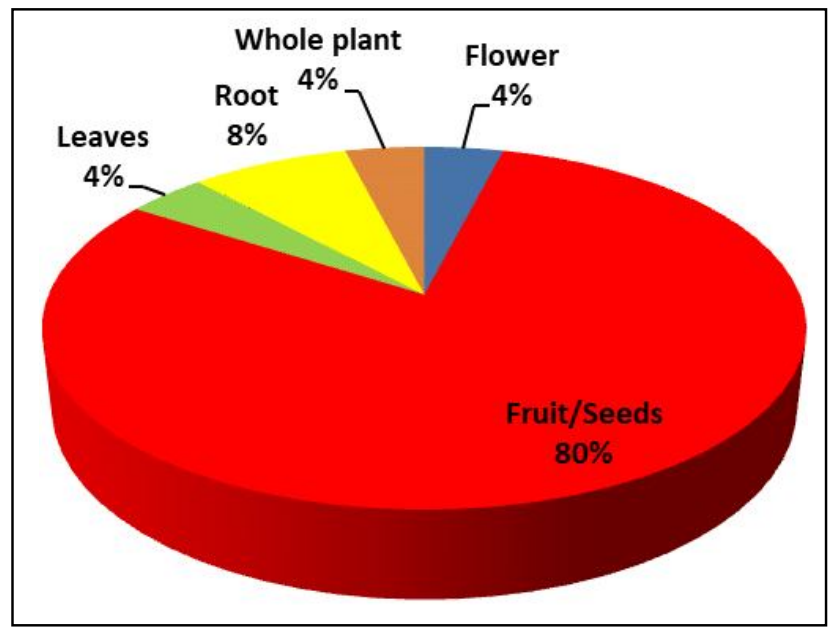

Figure 7: Usage of ajwayin (T. ammi) plant part.

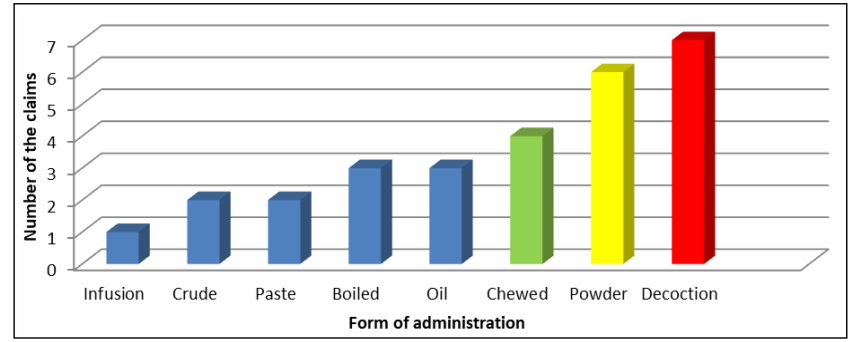

Figure 8 : Ajwayin (T. ammi) form of administration.

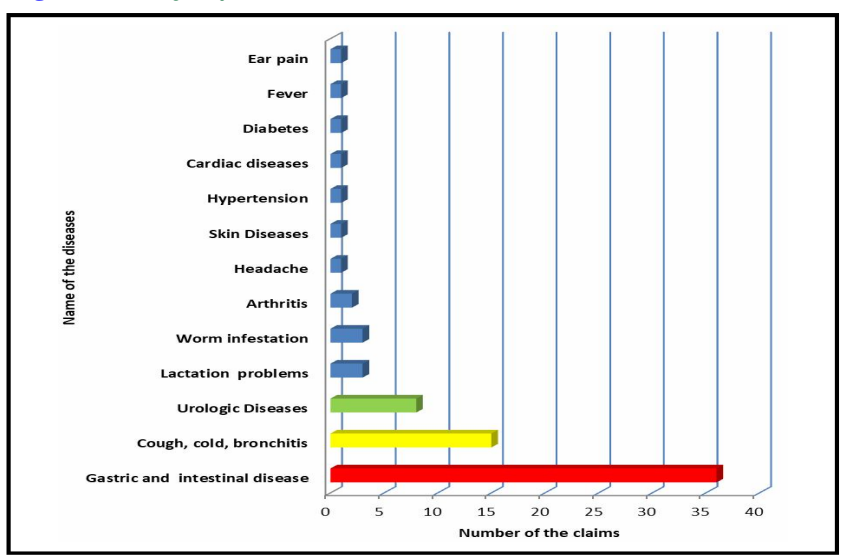

Figure 9: Ethnomedicinal uses of ajwayin (T. a mmi) in different disease conditions.

Table 2: Ethnomedicinal uses of ajwayin (T. ammi)

\begin{tabular}{|c|c|c|c|c|}
\hline S. No. & Part used & Ethnomedicine (Form) & Ethnomedicinal (Therapeutic) uses & References \\
\hline 1. & Seeds & Decoction & $\begin{array}{l}\text { Anorexia, arthrosis, ascites, asthma, atony, boil, } \\
\text { bronchitis, cachexia, cancer of abdomen, } \\
\text { cardiopathy, cholera, cold, colic, congestion, } \\
\text { cough }\end{array}$ & Asif et al., 2014 \\
\hline 2. & Seeds & Decoction & Bronchitis, atonic dyspepsia & Jan et al., 2015 \\
\hline 3. & Seeds & Decoction & Postnatal care & $\begin{array}{l}\text { Anvar and Haneef, } \\
2015\end{array}$ \\
\hline 4. & Seeds & Crude & Irregular menstruation & Jan et al., 2020 \\
\hline 5. & Seeds & Oil & Vitiligo & Kianifar et al., 2019 \\
\hline 6. & Root & Decoction & $\begin{array}{l}\text { Drenched once daily to camel and buffaloes } \\
\text { to treat cold and cough }\end{array}$ & Yadav et al., 2014 \\
\hline 7. & Seeds & Decoction & Galactagogue, uterine tonic, diuretic, antiemetic, & Goyal, 2017 \\
\hline 8. & Seeds & Boiled extract & For loss of appetite, abdominal obesity & $\begin{array}{l}\text { Rahman and Ahmed, } \\
2018\end{array}$ \\
\hline 9. & Seeds & Powder & $\begin{array}{l}\text { Diabetes, hypertension, diarrhea, asthma, } \\
\text { anthelminthic, diuretic }\end{array}$ & Demoz et al., 2015 \\
\hline 10. & Seeds & $\begin{array}{l}\text { Oil, oil external application, } \\
\text { powder }\end{array}$ & $\begin{array}{l}\text { Dyspepsia, Cholera, Flatulence, Bronchitis, } \\
\text { Asthma, rheumatic and neuralgic pains }\end{array}$ & Khan et al., 2016 \\
\hline 11. & Seeds & Powder along with salt & $\begin{array}{l}\text { Atonic dyspepsia, flatulence and spasmodic } \\
\text { disorders and are essential ingredient for mast } \\
\text { of the digestive powders }\end{array}$ & Dwivedi et al., 2006 \\
\hline 12. & Seeds & Powder, paste & $\begin{array}{l}\text { Bronchitis, stomach disorders in the cattle, } \\
\text { relief from colic }\end{array}$ & Lone et al., 2012 \\
\hline 13. & Fruits & Chewed & $\begin{array}{l}\text { Stomach disorder, antispasmodic and } \\
\text { carminative properties }\end{array}$ & Sharma et al., 2016 \\
\hline
\end{tabular}




\begin{tabular}{|c|c|c|c|c|}
\hline 14. & $\begin{array}{l}\text { Flower, root, } \\
\text { seeds }\end{array}$ & $\begin{array}{l}\text { Hydrodistillation, decoction, } \\
\text { raw/Oral }\end{array}$ & $\begin{array}{l}\text { To relieve colic pain, common cold, gastric } \\
\text { reflex, gastritis and nausea; as carminative } \\
\text { and vermifuge and to increase lactation in } \\
\text { nursing mothers; culinary uses }\end{array}$ & Moazzami et al., 2018 \\
\hline 15. & Leaves & Extract & Cold and cough & Reddy et al., 2006 \\
\hline 16. & Seeds & Powder, boiled & $\begin{array}{l}\text { Abdominal pain, swelling, appetite stimulant, } \\
\text { galactagogue, indigestion, }\end{array}$ & Abbasi et al., 2013 \\
\hline 17. & Seeds & Powder & Gastrointestinal diseases & Begum et al., 2021 \\
\hline 18. & Seeds & Infusion & Congestion, fever & Pande et al., 2015 \\
\hline 19. & Seeds & $\begin{array}{l}\text { Paste along with jiggery in } \\
\text { the form of pills }\end{array}$ & Diuresis & Shende et al., 2014 \\
\hline 20. & Seeds & Chewed & Indigestion and gastric disturbance & Khan, 2013 \\
\hline 21. & Seeds & Decoction & Pneumonia & Ullah et al., 2018 \\
\hline 22. & $\begin{array}{l}\text { Whole plant } \\
\text { and seed }\end{array}$ & Chewed & Headache, cough, ear diseases & Das and Hazarika, 2015 \\
\hline
\end{tabular}

\subsection{Phytoconstituents}

Agroclimatic conditions, time of cultivation, collection and different methods of extraction are the critical factors that contribute in the yield and composition of the essential oil (EO). Thymol is the major component of the EO; others include alpha- and beta-pinene, camphene, mycrene, delta-3-carene, limonene, gamma-terpinene, p-cymene, c-terpinene and carvacrol (Zarshenas et al., 2014).

Fruits also contain glycosides, carbohydrates, phenolic compounds, saponins, volatile oil (thymol, p-cymene, c-terpinene, and $\alpha$-and $\beta$-pinene), moisture (7.4); protein (17.1); fat (21.8); fibre (21.2); carbohydrates $(24.6 \%)$; vitamins and mineral matter calcium, phosphorus, iron, sodium, potassium, thiamine, riboflavin, nicotinic acid and carotene; protein, minerals $(\mathrm{Ca}, \mathrm{P}, \mathrm{Fe}$ and nicotinic acid); alkaloids (2.80-4.23\%), flavonoids (8.58-15.06\%), tannins (19.71$27.77 \%)$, saponins $(0.55-0.70 \%)$ and cardiac glycosides. Isolation of an anticalcifying protein from fruits and presence of choline and ACh extract of the seed was also reported (Hejazian et al., 2006; Kaur et al., 2009; Kavoosi et al., 2013; Boskabady et al., 2014).

Alkaloids, carbohydrates, phenol, phytosterols, tannins, and flavonoids are also reported from the methanol, aqueous, and acetone fruit extracts, nearly twenty five (25) compounds including; aromatic compound glucosides, glucosides, monoterpenoid, monoterpenoid glucides were also isolated from the water-soluble portion of methanol fruit extract (Ishikawa et al., 2001).

\subsection{Pharmacological actions}

A number of studies showed that ajwayin seeds (fruits) possessed broad pharmacological properties; antioxidant, antimicrobial, antinociceptive, antoconvulsant (Rezvani et al., 2011), cytotoxic, hypolipidemic, antihypertensive (Aftab et al., 1995), bronchodilation, abortifacient, antilithiasis, diuretic, antitussive, antifungal, nematicidal, anthelmintic, antifilarial , analgesic, anti-inflammatory, anxiolytic and antispasmodic activities.

\subsubsection{Antibacterial and antifungal activity}

Acetone fruits (seeds) extracts showed considerably good antibacterial activity against $E$. faecalis, $S$. aureus, $P$. aeruginosa,
Shigella flexneri and S. typhimurium. While, ethanol and acetone extracts were reported to be active against all of the above alongwith S. typhi, E. coli and Klebsiella pneumonia (Kaur and Arora, 2009). The methanol extract of the fruits significantly inhibited Pseudomonas aeruginosa (Bora et al., 2016). The petroleum ether extract exhibited the best activity against MDR strain of Candida albicans (Khan et al., 2010). Chloroform, methanol and acetone extracts at $6.25 \mathrm{mg} / \mathrm{ml}$ concentration showed high antibacterial effect on regular and IMP-producing P. aeruginosa strains collected from the hospitalized burn patients (Fallah et al., 2013). The EO was also reported to be active against $E$. cloacae, Salmonella, Citrobacter, V. cholerae, K. pasteurella, A. baumanii (Mayaud et al., 2008).

\subsubsection{Antioxidant activity}

Ajwayin fruits extract and its methanol fraction showed highest antioxidant activity by DPPH assay and phosphomolybdenum, followed by other fractions comparable to ascorbic acid and BHT (Zahin et al., 2010). Antioxidative activities of ethanol extracts obtained from Trachyspermum have been reported by the DPPH (2,2'-diphenyl-1-picrylhydrazyl) radical scavenging test, the studied extract exhibited antioxidant capability (Nickavar and Abolhasani, 2009).

\subsubsection{Antihypertensive activity}

Aqueous-methanolic extract of seeds (CSE 3-100 mg/kg) caused a dose-dependent fall in arterial blood pressure in anaesthetized rats. In isolated rabbit aorta and jejunum preparations, $0.1-3.0 \mathrm{mg} / \mathrm{ml}-$ CSE caused an inhibitory effect on the potassium ion $\left(\mathrm{K}^{+}\right)$-induced contractions. The calcium channel blocking (CCB) effect was checked when CSE shifted the calcium ion $\left(\mathrm{Ca}^{+2}\right)$ dose-response curves (DRCs) to right related to verapamil (Gilani et al., 2005).

\subsubsection{Antilithiasis activity}

Kaur et al. (2009) successfully purified an anticalcifying protein from the ajwayin seeds using oxalate depletion assay and deciphered its inhibitory activity against calcium oxalate crystal growth. The antilithiatic potential (preventiin of calcium oxalate deposition) of T. ammi anticalcifying protein (TAP) was confirmed in urolithiatic rat model, by its ability to maintain the renal functioning, reduced 
renal injury and decreased crystal excretion in urine and retention in renal tissues.

\subsubsection{Hepatoprotective activity}

Pretreatment of rats with seed extract $(500 \mathrm{mg} / \mathrm{kg}$ orally for 2 days at $12 \mathrm{~h}$ intervals) prevented carbon tetrachloride $\left(\mathrm{CCl}_{4}\right)$ and paracetamol induced rise in liver enzymes; aminotransferases (AST and ALT) and serum alkaline phosphatase (ALP). Further, confirming the hepatoprotectivity, the same dose of seed extract was able to prevent the $\mathrm{CCl}_{4}$-induced prolongation in pentobarbitalinduced sleeping time in mice (Gilani et al., 2005).

\subsubsection{Antifilarial activity}

The crude methanolic extract of fruits of T. ammi active fraction showed significant activities against the adult bovine filarial Setaria digitata worms by both a worm motility and 3-(4,5-dimethylthiazol2-yl)-2,5-diphenyl tetrazolium bromide (MTT) reduction assays. The isolated active principle was chemically characterized as phenolic monoterpene by the MS and NMR analysis. Further, the phenolic monoterpene was screened in vivo for antifilarial activity against the human filarial worm B. malayi in Mastomys coucha, exhibited macrofilaricidal activity and in vivo female worm sterility against B. malayi (Mathew et al., 2008).

\subsubsection{Other pharmacological activities}

Hydroalcoholic and polyphenolic extracts suppressed the naloxoneinduced withdrawal symptoms in morphine dependent mice as both the extracts inhibited tremor significantly (Ghannadi et al., 2012). Ether extract of omum (T. ammi) inhibited epinephrine, arachidonic acid, and collagen-induced platelet aggregation, by reducing platelet $\mathrm{TxB} 2$ production and inhibiting COX (Srivastava et al., 1988).

Ethanolic fruit extract of T. ammi produced significant increase in tail-flick latency (TFL) and exhibited short duration analgesic effect in mice comparable to $1 \mathrm{mg} / \mathrm{kg}$ - morphine (Dashti-Rahmatabadi et. $a l, 2007)$. Positive results in the analgesiometric test indicated that the antinociceptive action may be of the opoid type. The study supported the claims of Iranian traditional medicine that $T$. ammi (Carum copticum) extract exhibited a clear-cut analgesic effect. Oral administration of crude alcoholic extract of the fruits, n-hexane fraction, and EO produced immunomodulatory (immunestimulatory) effect to mice (Sonar et al., 2016).

\section{Flaxseed/alsi: Linum usitatissimum $\mathbf{L}$.}

Commonly known as flaxseed/alsi, atasi (Ayurved) and katan (Unani), belongs to Linaaceae family.

\subsection{Botanical description}

This annual herb, as a food and fiber crop, is mainly cultivated in, Mediterranean countries, Central Asia, Egypt, and southern Europe. Stems terete, erect, branched above; branches ascending towards apex. Leaves subsessile, linear to linear-lanceolate, attenuate at both ends, glabrous, 3-nerved. Flowers axillary, solitary or in broad cymes. Sepals long, ovate to elliptic, acuminate, prominently 3 nerved. Petals blue or purple, raiely white, obovate or broadly rounded. Stamens 5, connate at base. Ovary ovoid; styles free; stigmas linear-clavate, often cohering. Capsules globose, mucronate, scarcely exceeding sepals, apex rounded, dehiscing incompletely, segments falling freely, margins ciliate. Seeds brown, 6-9 mm long, oblong, flattened, elongated ovoid form, with an acute edge, and a slightly oblique point blunt at one end. Seeds have a brown glossy surface, which under a lens is seen to be marked with extremely fine pits. The hilum occupies a slight hollow in the edge just below the apex. Water soaked seeds slightly swelled and surrounded by a thin, colorless mucous envelope, which quickly dissolves to form a neutral jelly. Flower and fruiting-January-August.

\subsection{Parts used}

Seeds

\subsection{Historical background}

Flaxseeds/alsi (Linseed), is one of the most ancient crops, native of Egypt. It was valued in ancient and early modern times both as a functional food and medicine (Hasler et al., 2000). In India and many parts of the world, alsi is cultivated mainly as an oil seed plant and fibre.

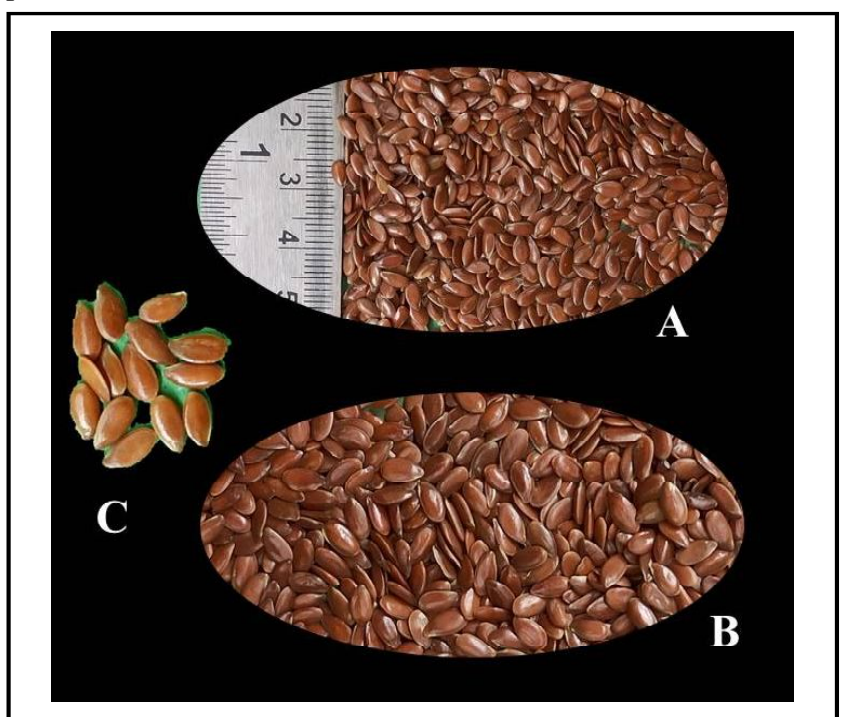

Figure 10:10A-B. Alsi (L. usitatissimum) seeds, 10C. flaxseed fruits (enlarged view).

It has been used frequently in Unani and other Traditional systems of medicine since long time. The medicinal uses of flaxseed is mentioned in the works of Hippocrates, Pliny and Dioscorides as well as in the books of medieval era. Ibn al-Baitar described flax as a worthy abortifacient, and further quoted Dioscorides that using it after mixing with Piper nigrum (black pepper) and honey stimulates the sexual desire. Manual flax processing originated in Egypt in 2000 B.C. (Ibn al-Baitar, 2003; Noweir et al.,1975).

\subsection{Therapeutic actions and uses}

Linseed tea (25 g of ground or entire seeds to $30 \mathrm{cc}$ of boiling water), added with little honey and lemon juice, used as a demulcent drink in cough due to irritated and inflamed pharynx, is taken for colds, coughs, irritation of the urinary organs, gastritis and enteritis. Seeds are taken internally for irritation in the digestive tract. The seeds absorb fluid and swell, forming a jelly-like mass that acts as an effective bulk laxative. The use of large quantity of seeds with low water/fluid intake could lead to severe intestinal obstruction. In folk medicine, linseed is used for removing a foreign body from 
the eye, by moistened a linseed and placing under the eyelid (Khare et al., 2004; Kritikar and Basu, 1954).

The external application of the alsi oil with lime-water to burns is very beneficial; and taking internally helps atherosclerosis and nephritis. Alsi oil was used in painter's colic and other spasmodic affections of the bowel (Dymock et al., 1972). The oil with an equal part of lime-water forms-carron oil, and was used for scalds and burns, given internally (approx. $60 \mathrm{ml}$ ) as an aperient for piles (Dymock et al., 1972). Alsi seeds are now being increasingly used in food, as laxatives and as dietary health supplements for menopausal symptoms (Flower et al., 2014), due to the presence of $\alpha$-linolenic acid (ALA) and their high content of omega-3 fatty acid. ALA is suggested to positively impact cardiovascular diseases (Rodriguez-Leyva et al., 2010).

Unani physicians consider the temperament of alsi/katan as hot $1^{\circ}$ and dry $1^{\circ}$. The seeds of alsi are anti-inflammatory, analgesic, aphrodisiac, concoctive, resolvent, mucolytic, laxative, concoctive and useful in wound healing. The flowers are considered as cardiotonic. Poultice of alsi is recommended for rheumatic and gouty swellings. Alsi alongwith honey is usually prescribed for coughs and colds. Alsi oil is externally used for internal inflammations, such as; arthritis, pleurisy and pneumonia (Kabeeruddin, 1937; Ghani, 1920; Ibne al Baitar, 2003).

\subsection{Ethnobotanical uses}

Alsi plants particularly seeds are medicinally used in different forms for the treatment of a number of diseased conditions. The methods of preparation, uses and its application are well documented in the common ethnobotanical literature. The plant is ethnomedicinally used to treat arthritis, abdominal pains, laxative, and colic pain. Some important information on ethnomedicinal uses has been summarized in Table 3.

A survey of the available ethnobotanical literature on alsi showed that most of the workers have reported that all plant parts are employed for the treatment of different diseases but seeds are the most commonly utilized plant part with $88 \%$ utilization followed by fruits $(6 \%)$, and leaves (6\%) (Figure 11).

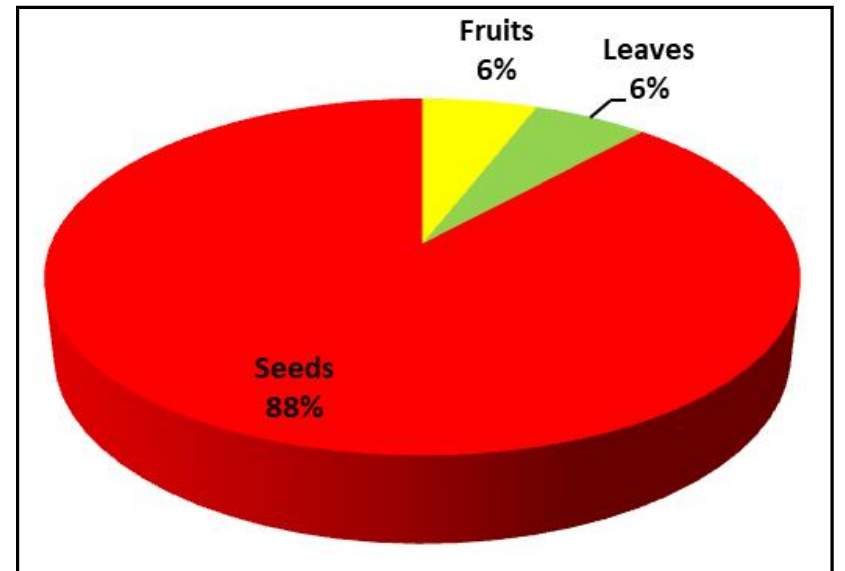

Figure 11: Usage of alsi (L. utisamimmum) plant part.

As far as administration is concerned, majority of the claims are recorded in the form of powder, followed by boil (Figure 12). Most of the workers reported its ethnomedicinal use on disease conditions like gastric and intestinal diseases (maximum-6), followed by cough, cold, bronchitis ( 5 nos.), skin diseases (5 nos.), painful inflammations (3 nos.), cardiac diseases ( 2 nos.), diabetes (2 no.) and urological diseases (1 no.) and sexual transmitted diseases (1 no.) (Figure 13).

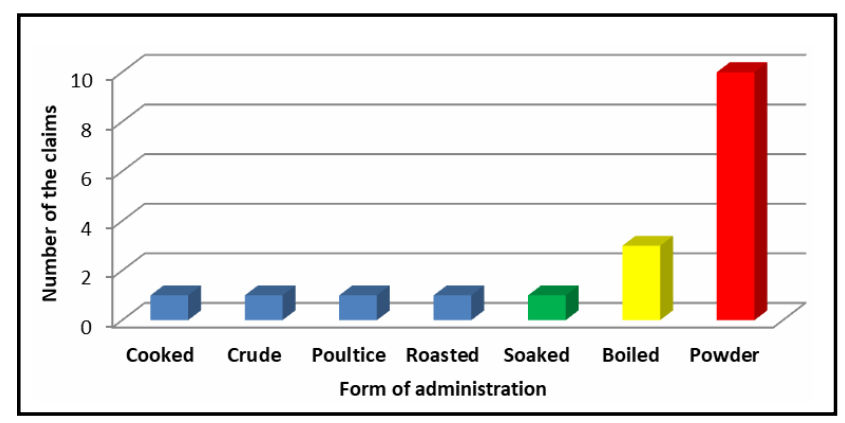

Figure 12: Form of administration.

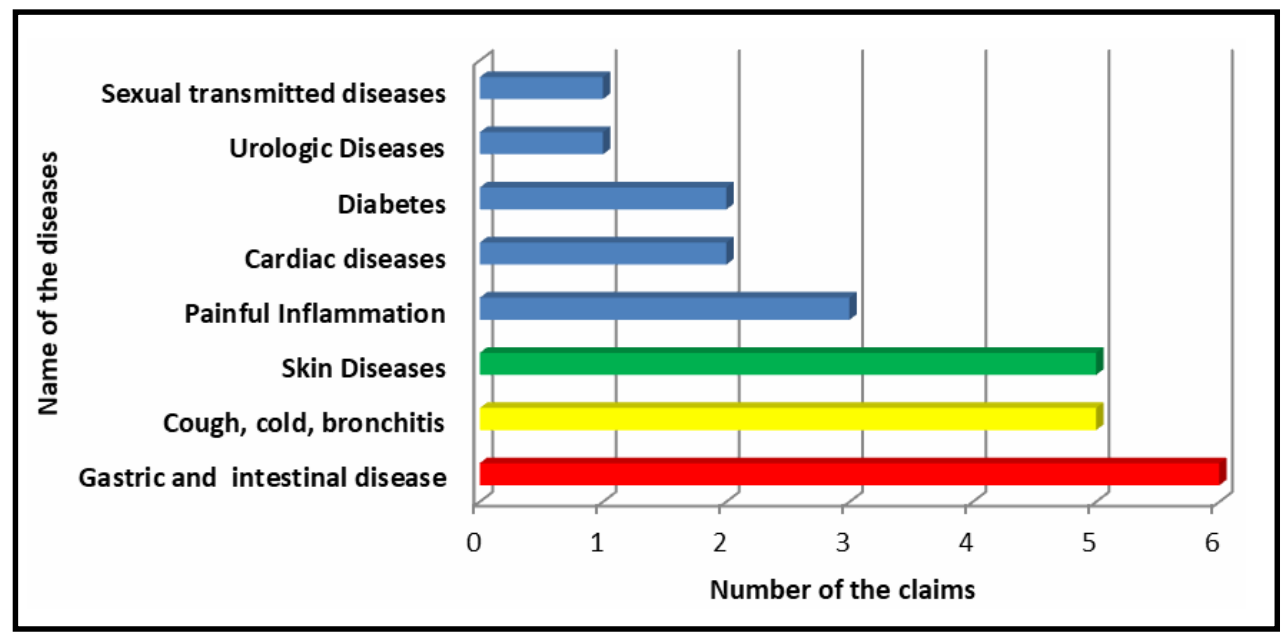

Figure 13: Ethnomedicinal uses of alsi (L. utisamimum) in different disease conditions. 
Table 3: Ethnomedicinal uses of alsi (L. utisamimmum)

\begin{tabular}{|c|c|c|c|c|}
\hline S. No. & Part used & Ethnomedicine (Form) & Ethnomedicinal (Therapeutic) uses & Reference \\
\hline 1. & Seeds & $\begin{array}{l}\text { Oil along with calcium } \\
\text { carbonate powder }\end{array}$ & $\begin{array}{l}\text { Skin burns, cough, asthma, control cholesterol } \\
\text { level, warts }\end{array}$ & Ahmad et al., 2018 \\
\hline 2. & Fruits & Coocked & Inflammation of liver and kidney & Andrade et al., 2017 \\
\hline 3. & Seeds & Poultice & Inflammation, abscesses, ulcers or burn & Mohamadi et al., 2015 \\
\hline 4. & Seeds & Boiled and applied externally & Colds and coughs in animals & $\begin{array}{l}\text { Pieroni Andrea and } \\
\text { Giust, } 2009\end{array}$ \\
\hline 5 . & Seeds & Powder & Soften hair & Mostafa et al., 2021 \\
\hline 6. & Seeds & Powder & Respiratory diseases & Bouredja et al., 2017 \\
\hline 7. & Seeds & Powder & $\begin{array}{l}\text { Used for constipation, controlling levels of } \\
\text { cholesterol and blood sugar in the body. }\end{array}$ & Kumar, 2019 \\
\hline 8. & Seeds & Powder & Constipation & Arenas et al., 2013 \\
\hline 9. & $\begin{array}{l}\text { Leaves and } \\
\text { Seeds }\end{array}$ & Powder & Diabetes & Hachi et al., 2017 \\
\hline 10 . & Seeds & Powder & Flatulence & Ali et al., 2019 \\
\hline 11. & Seeds & Boiled & Wounds, scar & Karakaya et al., 2020 \\
\hline 12. & Seeds & Powder & Gonorrhoea, backache & Sharma et al., 2015 \\
\hline 13. & Seeds & Crude & Laxative in cattle & Kumar et al., 2017 \\
\hline 14. & Seeds & Soaked in water & Gastritis & Gebre et al., 2021 \\
\hline 15 . & Seeds & $\begin{array}{l}\text { Roasted and pounded, boiled } \\
\text { in milk }\end{array}$ & Cough, pains & Ertug et al., 2000 \\
\hline 16. & Seeds & Powder & Diarrhoea and boils & Khare, 2017 \\
\hline
\end{tabular}

\subsection{Phytoconstituents}

The alsi plant contains; chlorogenic acid and its isomer, fatty oil with linoleic (40-70\%), stearic palmitic, oleic acids (13-30\%), along with sugars and amino acids. High swelling capacity of alsi is due to the presence of 3-10\% mucilages in the epidermis. It also contains cyanogenic glycosides $(0.1 \%)$; linustatin and neolinustatin. Cyanogenic glucosides (neolinustatin) in seeds are not reported to be toxic in therapeutic uses as these are broken down in the body only to a limited extent. Nevertheless, the cyanogenic glucosides are responsible for the deaths of the livestock grazing on the linseed plant. Veterinary meal (flaxseed) is reported to possess goitrogenic effect on sheep and mice due to the presence of thiocyanate (Khare, 2004).

A lignan complex, secoisolariciresinol diglucoside (SDG) present in the seeds (Schmidt et al., 2012). Cyclic peptides, cyclolinopeptides F-I, have also been isolated from the seeds (Matsumoto et al., 2001). The viscous seed mucilage is a mixture of rhamnogalacturonan I and arabinoxylan (Naran et al., 2008). Levels of p-coumaric acid, caffeic acid, and ferulic acid, and SDG are not significantly different between fiber and alsi oil, suggesting equal value of fiber as a functional food. Presence of omega-3, omega-6 rich oil, SDG, protein and minerals justifies their utilization for health benefits (Wang et al., 2017; Akhtar et al., 2013).

\subsection{Pharmacological activities}

In mice, pretreatment with flax seed oil ameliorates CP-induced oxidative stress (Bhatia et al., 2006). Antioxidant enzymes, such as; CAT, SOD, and peroxidase were restored after feeding rats with alsi seed supplemented diet. The enzymes were decreased by the carbon tetrachloride $\left(\mathrm{CCl}_{4}\right)$ challenge (Rajesha et al., 2006). Alsi oil also inhibited histamine, bradykinin PGE2, and leukotriene induced inflammation (Kaithwas et al., 2011).

Alsi seed or SDG-supplemented diet in rats reduced the IGF-I (plasma insulin-like growth factor I), which is associated with the increased risk of breast cancer (Rickard et al., 2000). Alsi seed reduced the metastasis and inhibited the growth of metastatic secondary tumors in animals (Yan et al., 2018). Alsi seed and SDG treatment delayed the progression of mammary tumors induced by N-methyl-N-nitrosourea (Rickard et al.,1999) and significantly reduced the plasma plasma insulin-like growth factor -I concentrations in rats (Rickard et al., 2000).

Alsi seed supplemented diet significantly reduced the body weight and fat accumulation, improved the lipid profile, and blood pressure in high-fat diet-treated rats (Park and Velasquez, 2012). Alsi lignan complex and isolated SDG reduced the acceleration of cholesterolinduced aortic atherosclerotic lesions and also reduced the oxidative stress in rabbits (Prasad, 2007, 2008). Flaxseed supplemented diet significantly decreased body mass, LDL-C, glucose and uric acid, and increased HDL-C in 47\% of normal rats (Tomaz Pacheco et al., 2011). Flaxseed meal also significantly lowered fat deposition in livers, significantly lowered LDL-C, HDL-C, and TGs in obese phenotype rats (Bhathena et al., 2003).

Flax lignan complex suppressed the development of hypercholesterolemic atherosclerosis with reductions in oxidative 
stress (Prasad, 2005, 2009), and protected rats against lead acetateinduced oxidative damage and hyperlipidemia (Newairy et al., 2009). Alsi seed supplemented diet to diabetic hamsters significantly reduced, TC/HDL-C ratio, serum and increased serum HDL-C without affecting serum triglycerides (Haliga et al., 2007).

Pretreatment of rats with flaxseed oil substantially protected against various experimental gastric ulcers (Kaithwas and Majumdar, 2010). The oil also significantly inhibited pylorus and forestomach ligationinduced esophagitis, gastric secretion, and total acidity (Renu et al., 2012). Moderate to high doses of partially defatted alsi seed meal markedly increased the frequency of stool and weight in normal and constipated mice both (Xu et al., 2012).

Alsi seed and oil in diet are renoprotective in rat model of polycystic kidney disease and ameliorated the associated chronic interstitial nephritis (Sankaran et al., 2006, 2007) and prevented rise in blood pressure and significantly attenuated increase in plasma TC and TGs of rats after few nephrectomy (Ingram et al., 1995). Dietary flaxseed and its extracts also reduced oxidative stress in diabetic nephropathy (Kaur et al., 2017) and protected against $\mathrm{CCl}_{4}$ hepatotoxicity (Hemmings and Song, 2005) .

Alsi seeds and SDG produced antiestrogenic effect in rats. The higher relative sex organ weights and prostate cell proliferation of male rat produced by the lifetime exposure to higher dose of flaxseed. It also raised the serum testosterone and estradiol levels. While, lower dose exposure reduced adult relative prostate weight and cell proliferation (Tou et al., 1998, 1999).

\section{Conclusion}

Over the past few years, the traditional herbal plants have gained a wide recognition due to lesser side effects as compared to allopathic medicines. The natural herb and remedies deliberated in this article as; fennel, ajwayin and alsi are used traditionally in AYUSH Ayurveda and Unani systems of medicine for general health and longevity since long. Further, the phytoconstituents have some definite role that has been evidenced scientifically. These herbs contain certain essential oils (EO), phenolic compounds, flavonoids and many more useful components and have antioxidant, antimicrobial, anticancer, anti-inflammatory and antidiabetic activities. Each and every property of their active ingredients plays the important roles in human health progression. The medicinal herb has been employed in most of the traditional practices and now is a way to maintain quality of life $(\mathrm{QoL})$ and health in the large part of the globe. In addition to that, the highly potential ethnobotanical knowledge of tribes living in the remote areas not only depend upon the medicinal plants as a source of medicine to deal with different disease conditions, but these people have also exclusively developed the methods of resource management for other day-to-day purposes including; food, fodder and fuel.

\section{Future prospects}

It would be a great asset, if this traditional/ethnobotanical knowledge on the herbs is further subjected to the scientific validation by more advanced pharmacological and clinical studies. Such investigations could draw attention to the discovery of newer drugs of plant origin for the treatment of different diseases, for which there is little or no adequate cure is available in the modern medicines. The need of the hour is to conduct the multiple clinical trials to draw compelling evidence for highlighting the mechanism of action and dose adjustment. Further studies could be conducted to get evidence on herb-drug interactions, which is sometimes lethal when we use modern medicines along with the herbal regime.

\section{Acknowledgements}

Author gratefully acknowledged Professor Asim Ali Khan, DirectorGeneral, Central Council for Research in Unani Medicine (CCRUM), New Delhi, Ministry of AYUSH, Govt. of India and Dr. G.P. Pratap, NRIUMSD, Hyderabad for the support and encouragement.

\section{Conflict of interest}

The author declares no conflicts of interest relevant to this article.

\section{References}

Abbasi, A.M.; Khan, S.M.; Ahmad, M.; Khan, M.A.; Quave, C.L. and Pieron, A. (2013). Botanical ethnoveterinary therapies in three districts of the lesser Himalayas of Pakistan. Journal of Ethnobiology and Ethnomedicine, 9:84. DOI https://doi.org/10.1186/1746-4269$9-84$

Aftab, K.; Atta-Ur-Rahman and Usmanghani, K. (1995). Blood pressure lowering action of active principle from Trachyspermum ammi (L.) sprague. Phytomedicine, 2(1):35-40. doi:10.1016/S09447113(11)80046-2.

Ahmad, M.; Zafar, M.; Shahzadi, N.; Yaseen, G.; Murphey,T.M. and Sultana, S. (2018). Ethnobotanical importance of medicinal plants traded in herbal markets of Rawalpindi-Pakistan. Journal of Herbal Medicine, 11:78-89.

Akgul, A. and Bayrak, A. (1988). Comparative volatile oil composition * of various parts from Turkish bitter fennel (Foeniculum vulgare var. vulgare). Food Chemistry, 30(4):319-323.

Akhtar, S.; Ismail T. and Riaz, M. (2013). Flaxseed-a miraculous defense against some critical maladies. Pak. J. Pharm. Sci., 26:199-208.

Albert-Puleo, M. (1980). Fennel and anise as estrogenic agents. Journal of Ethnopharmacology, 2(4):337-344

Albuquerque, U.P.; Medeiros P.M.; Almeida,A.L.; Monteiro, J.M.; Neto E.M.F.L.; Melo, J.G. and Santos J.P.D. (2007). Medicinal plants of the caatinga (semi-arid) vegetation of NE Brazil: A quantitative approach. Journal of Ethnopharmacology, 114(3):325-354.

Ali, M.; Aldosari, A.; Tng, D. Y.; Ullah, M.; Hussain, W.; Ahmad, M.; Hussain, J.; Khan, A.; Hussain, H.; Sher, H.; Bussmann, R. W. and Shao, J.W. (2019). Traditional uses of plants by indigenous communities for veterinary practices at Kurram District, Pakistan. Ethnobotany Research and Applications, 18:1-19.

Alzweiri, M.; Sarhan, A. A.; Mansi, K.; Hudaib, M. and Aburjai, T. (2011). Ethnopharmacological survey of medicinal herbs in Jordan, the Northern Badia region. Journal of Ethnopharmacology, 137(1): 27-35

Andrade, J.M.; Mosquera, H.L. and Armijos, C. (2017). Ethnobotany of indigenous saraguros: Medicinal plants used by community healers "Hampiyachakkuna" in the San Lucas Parish, Southern Ecuador. BioMed Research International, pp:1-20. Article No:D 9343724.

Andrew, C. (2016). Encyclopaedia of Herbal Medicine. $3^{\text {rd }}$ ed., DK Publishing, New York. pp:212.

Anvar, K.; and Haneef, J. (2015). Ethnobotanical plants used for postnatal care by traditional practitioners from Kozhikode district, Kerala, India. International Journal of Research in Pharmacy and Chemistry, 5(4):570-581. 
Arenas, P.M.; Molares, S.; Contreras, A.A.; Doumecq, B. and Gabrielli, F. (2013). Ethnobotanical, micrographic and pharmacological features of plant-based weight-loss products sold in naturist stores in Mexico City: The need for better quality control. Acta Botanica Brasilica, 27(3):560-579.

Asif, H.M.; Sultana, S. and Akhtar, N. (2014). A panoramic view on phytochemical, nutritional, ethanobotanical uses and pharmacological values of Trachyspermum ammi Linn. Asian Pacific Journal of Tropical Biomedicine, 4(2):545-553. DOI:10.12980/ APJTB.4.2014AP JTB-2014-0242.

Badgujar, S.B.; Patel, V.V. and Bandivdekar, A.H. (2014). Foeniculum vulgare Mill.: A review of its botany, phytochemistry, pharmacology, contemporary application, and toxicology. Biomed. Res. Int., 14:842-874

Bairwa, R.; Sodha, R.S. and Rajawat, B.S. (2012). Trachyspermum ammi. Pharmacogn. Rev., 6(11):56-60. DOI: 10.4103/0973-7847.95871.

Begum, M.; Sharma, B.P. and Aziz, B.S.M. (2021). Ethnobotanical, phytochemical and pharmacological scence of Trachyspermum ammi (Ajwain): A systematic review. Int. J. Pharm. Sci. and Res., 12(11):5690-5697. DOI: 10.13040/IJPSR.0975-8232.12(11). 5690-97.

Bhathena, S.J.; Ali. A.A.; Haudenschild, C.; Latham, P.; Ranich, T.; Mohamed, AI.; Hansen, C.T. and Velasquez, M.T. (2003). Dietary flaxseed meal is more protective than soy protein concentrate against hypertriglyceridemia and steatosis of the liver in an animal model of obesity. J. Am. Coll. Nutr., 22(2):157-164. doi:10.1080/07315724.2003. 10719289.PMID: 12672712 .

Bhatia, AL.; Manda, K.; Patni, S. and Sharma, AL. (2006). Prophylactic action of linseed (Linum usitatissimum) oil against cyclophosphamideinduced oxidative stress in mouse brain. J. Med. Food., 9:261264.

Birdane, F.M.; Cemek, M.; Birdane, Y.O.; Gülçin, I. and Büyükokuroðlu, M.E (2007). Beneficial effects of Foeniculum vulgare on ethanolinduced acute gastric mucosal injury in rats. World J. Gastroen. Terol., 13(4):607-611. DOI:10.3748/wjg.v13.i4.607.

Boon, H.S.; Olatunde. F. and Zick, S.M. (2007). Trends in complementary/ alternative medicine use by breast cancer survivors: Comparing survey data from 1998 and 2005. BMC Women's Health, 7:4 (DOI: $10.1186 / 1472-6874-7-4$ )

Bora, L. (2016). Anticandidal activity of medicinal plants and Pseudomonas aeruginosa strains of clinical specimens. J. Microbiol. Immunol. Infect., 49(2):276-280. DOI: 10.1016/j.jmii. 2014.10. 002 .

Boskabady, M.H.; Alitaneh, S. and Alavinezhad, A. (2014). Carum copticum L.: A herbal medicine with various pharmacological effects. Biomed. Res. Int., 14:569-687. DOI:10.1155/2014/569087.

Boskabady, M.H.; Khatami, A. and Nazari, A. (2004). Possible mechanism(s) for relaxant effects of Foeniculum vulgare on guinea pig tracheal chains. Pharmazie., 59(7):561-564.

Bouredja, N; Mekdad, H. and Baghdadi. K. (2017). Ethnobotany and floristic study of medicinal plants used in the treatment of respiratory diseases in the industrial region (Arzew) Oran, Algeria. GSC Biological and Pharmaceutical Sciences, 1(2):41-48.

Breyer-Brandwijk, M.G. and Watt, J.M. (1962). The medicinal and poisonous plants of southern and Eastern Africa. 2nd Edition, E. and S. Livingstone Ltd., Edinburgh.

Bulut, G. and Tuzlaci, E. (2013). An ethnobotanical study of medicina plants in Turgutlu (Manisa-Turkey). Journal of Ethnopharmacology, 149(3):633-647.
Cabral, C.; Miranda, M.; Gonçalves, M.J.; Cavaleiro, C.; Cruz, M.T. and Salgueiro, L. (2017). Assessment of safe bioactive doses of Foeniculum vulgare Mill. essential oil from Portugal. Nat. Prod. Res., 31(22):26542659. DOI: 10.1080/14786419.2017.1292266.

Carrio, E. and Valles, J. (2012). Ethnobotany of medicinal plants used ' in Eastern Mallorca (Balearic Islands, Mediterranean Sea). J. Ethnopharmacol., 141(3):1021-1040.

Choi, E. and Hwang, J. (2004). Antiinflammatory, analgesic and antioxidant activities of the fruit of Foeniculum vulgare. Fitoterapia, 75(6) $557-565$.

Cosge, B.; Kiralan, M. and Gürbüz, B. (2008). Characteristics of fatty acids and essential oil from sweet fennel (Foeniculum vulgare Mill. var. dulce) and bitter fennel fruits (F. vulgare Mill. var. vulgare) growing in Turkey. Nat. Prod. Res., 22(12):1011-1016. DOI: $10.1080 / 14786410801980675$.

D’iaz-Maroto, M. C.; Perez-Coello, M. S.; Esteban, J. and Sanz, J. (2006). Comparison of the volatile composition of wild fennel samples (Foeniculum vulgare Mill.) from Central Spain. Journal of Agricultural and Food Chemistry, 54(18):6814-6818.

Das, A.K. and Hazarika, M. (2015). Study of diversity of ethnobotanical plants used by the mishing tribes of golaghat district, Assam and their conservation. International Journal of Recent Scientific Research, 6(7):4992-4998.

Dashti-Rahmatabadi, M.H.; Hejazian, S.H.; Morshedi, A. and Rafati, A. (2007). The analgesic effect of Carum copticum extract and morphine on phasic pain in mice. J. Ethnopharmacol., 109(2):226-228. DOI: $10.1016 / \mathrm{j} . j$ ep.2006.07.035

Demoz, M.S.; Gachoki, K.P.; Mungai, K.J. and Negusse, B.G. (2015) Ethnobotanical survey and preliminary phytochemical studies of plants traditionally used for diabetes in eritrea. European Journal of Medicinal Plants, 9(2):1-11. Article No. EJMP.18777

Díaz-Maroto, M.C.; Pérez-Coello, M.S.; Esteban, J. and Sanz, J. (2006). Comparison of the volatile composition of wild fennel samples (Foeniculum vulgare Mill.) from central Spain. J. Agric. Food Chem., 54(18):6814-6818. DOI: 10.1021/jf0609532.

Díaz-Maroto, M.C.; Díaz-Maroto, H.I.J.; Sánchez-Palomo E. and Pérez-Coello, M.S. (2005) Volatile components and key odorants of fennel (Foeniculum vulgare Mill.) and thyme (Thymus vulgaris L.) oil extracts obtained by simultaneous distillation-extraction and supercritical fluid extraction. J. Agric. Food. Chem., 53(13):53855389.

Dwivedi, S. and Patel, P.C. (2006). Medicinal plants used by the tribal and rural people of Satna district, Madhya Pradesh for the treatment of gastrointestinal diseases and disorders. Natural Product Radiance, 5(1)60-63.

Dymock, W.; Warden, C.J.H. and Hooper, D. (1972). Pharmacographia Indica, Reprinted by The Institute of Health and Tibbi Research, Hamdard National Foundation, Karachi, Pakistan. Voll-I-III, pp:1890, 1891,1893

Endalamaw, F.D. and Chandravanshi, B.S. (2015). Levels of major and trace elements in fennel (Foeniculum vulgare Mill.) fruits cultivated in Ethiopia. Springerplus, 4(1):1-10. doi: 10.1186/2193-18014-5.

Ernst, E. (2009). Complementary and alternative medicine (CAM) and cancer: The kind face of complementary medicine. Int. J. Surg., 7:499-500. 
Ertug, F. (2000). An ethnobotanical study in central Anatolia (Turkey) Economic Botany, 54(2):155-182.

Es-Safi, I.; Mechchate, H.; Amaghnouje, A.; Jawhari, F. Z.; Bari, A.; Cerruti, P.; Avella, M.; Grafov, A. and Bousta, D. (2020). Medicinal plants used to treat acute digestive system problems in the region of Fez-Meknes in Morocco: An ethnopharmacological survey. Ethnobot. Research Appl., 20:1-14.

Fallah. F.; Taherpour, A.; Borhan, R.S.; Hashemi, A.; Habibi, M. and Nia, R.S. (2013). Evaluation of Zataria multi flora Boiss and Carum copticum antibacterial activity on IMP-type metallo-beta-lactamaseproducing Pseudomonas aeruginosa. Ann. Burns. Fire. Disasters., 26(4):193-198.

Faudale, M.; Viladomat, F.; Bastida, J.; Poli, F. and Codina, C. (2008) Antioxidant activity and phenolic composition of wild, edible, and medicinal fennel from different Mediterranean countries," Journal of Agricultural and Food Chemistry, 56(6):1912-1920.

Flower, G.; Fritz, H.; Balneaves, L.G.; Verma, S.; Skidmore, B.; Fernandes, R.; Kennedy, D.; Cooley.; K, Wong, R.; Sagar, S.; Fergusson, D. and Seely, D. (2014). Flax and breast cancer: A systematic review. Integr Cancer Ther., 13(3):181-192. DOI: 10.1177/1534735413502076

Gebre, T. and Chinthapalli, B. (2021). Ethnobotanical study of the traditional use and maintenance of medicinal plants by the people of aleta-chuko woreda, south ethiopia. Pharmacogn. J., 13(5): 1097-1108.

Ghanem, M. T. M.; Radwan, H. M.A.; Mahdy, E. M.; Elkholy, Y. M.; Hassanein, H. D. and Shahat A. A. (2012). Phenolic compounds from Foeniculum vulgare (Subsp. Piperitum) (Apiaceae) herb and evaluation of hepatoprotective antioxidant activity," Pharmacognosy Research, 4(2):104-108.

Ghani, N. (1920) Khazainul Advia.: Sheikh, Basheer Ahmad and Sons, Lahore, pp:870.

Ghannadi, A.; Hajhashemi, V. and Abrishami, R. (2012). Effects of the Persian Carum copticum fruit extracts on morphine withdrawal syndrome in mice. Res. Pharm. Sci., 7(3):127-131.

Gilani, A.H.; Jabeen, Q.; Ghayur, M.N.; Janbaz, K.H. and Akhtar, M.S. (2005) Studies on the antihypertensive, antispasmodic, bronchodilator and hepatoprotective activities of the Carum copticum seed extract. J. Ethnopharmacol., 98(1-2):127-135. DOI: 10.1016/ j.jep.2005.01.017.

Gori, L.; Gallo, E. and Mascherini, V. (2012). Can estragole in fennel seed decoctions really be considered a danger for human health? A fennel safety update. Evid Based Complement Alternat Med., 12:860-892

Goyal, M. (2017). Use of ethnomedicinal plants for prophylaxis and management of postpartum complications among the Marwari community of Jodhpur District of Rajasthan. Food Quality and Safety, 1(3)203-210. https://doi.org/10.1093/fqsafe/fyx013

Grae, I. (1974). Nature's Colors-Dyes from Plants, MacMillan, New York, NY, USA

Gross, M.; Lewinsohn, E.; Tadmor, Y.; Bar,E.; Dudai, N.; Cohen,Y. and Friedman, J. (2009). The inheritance of volatile phenylpropenes in bitter fennel (Foeniculum vulgare Mill. var. vulgare, Apiaceae) chemotypes and their distribution within the plant, Biochemical Systematics and Ecology, 37(4):308-316.

Guarrera, P. M. and Savo, V. (2013). Perceived health properties of wild and cultivated food plants in local and popular traditions of Italy: A review. J. Ethnopharmacol., 146(3):659-680.
Guarrera, P. M.; Forti, G. and Marignoli, S. (2005). Ethnobotanical and ethnomedicinal uses of plants in the district of Acquapendente (Latium, Central Italy). J. Ethnopharmacol., 96(3):429-444.

Guarrera, P. M.; Salerno, G. and Caneva, G. (2005). Folk phytotherapeutical plants from Maratea area (Basilicata, Italy). J. Ethnopharmacol., 99(3):367-378.

Guillen, M. D. and Manzanos, M. J. (1996). A study of several parts of 'the plant Foeniculum vulgare as a source of compounds with industrial interest. Food Res. Internat., 29(1):85-88.

Guimarães, R.; Barreira, J.C.; Barros, L.; Carvalho, A.M. and Ferreira, I.C. (2011). Effects of oral dosage form and storage period on the antioxidant properties of four species used in traditional herbal medicine. Phytother. Res., 25(4):484-492. DOI:10.1002/ptr. 3284 .

Hachi, M.; Ouafae, B.; Hachi, T.; Mohamed B.E.; Imane, B. and Atmane, R. (2016). Contribution to the ethnobotanical study of antidiabetic medicinal plants of the Central Middle Atlas region (Morocco)/ Contribución al estudio etnobotánica de plantas medicinales antidiabéticas de la región central Oriente Atlas (Marruecos). Lazaroa, 37:135-144.

Hakeem, M.A. (2002). Bustanul Mufradat. Idara kitabus Shifa, New Delhi, pp:356.

Halberstein, R. A. (2012). Botanical medicines for diuresis: crosscultural comparisons. Studies in Natural Products Chemistry, 37:1-41.

Haliga, R.; Mocanu, V. and Oboroceanu, T.; Stitt, P.A. and Luca, V.C. (2007). The effects of dietary flaxseed supplementation on lipid metabolism in streptozotocin-induced diabetic hamsters. Rev. Med. Chir. Soc. Med. Nat. Iasi., 111:472-476. PMID: 17983187.

Hasler, C.M.; Kundrat, S. and Wool, D. (2000). Functional foods and cardiovascular disease. Curr. Atheroscler. Rep., 2(6):467-475. doi: 10.1007/s 1 1883-000-0045-9.

Hejazian, S.H. (2006). Analgesic effect of essential oil (EO) from Carum copticum in mice. World J. Med. Sci., 1:95-99.

Hemmings, S.J. and Song, X. (2005). The effects of dietary flaxseed on the Fischer 344 rat. III. Protection against $\mathrm{CCl}(4)$-induced liver injury. Cell Biochem Funct., 23:389-398.

Husain, M.K.; Khalid, M.; Pratap, G. P.; and Kazmi, M. H. (2017). Relevance of traditional Unani (Greco-Arab) system of medicine in cancer: An update. In: Anticancer plants: Clinical trials and nanotechnology (eds. Akhtar M., Swamy M.). Springer, Singapore. pp: 273-302. https://doi.org/10.1007/978-981-10-8216-0_10.

Husain, M.K.; Pratap, G.P.; Aminuddin and Kazmi, M.H. (2015). Ethnopharmacological uses of medicinal plants in Jannaram Forest Division of Telangana, India. Hippocratic J. Unani Med., 10(4):122-133.

Husain, M.K.; Pratap, G.P.; Aminuddin and Kazmi, M.H. and Rahman, R (2016). Folk-claims on medicinal plants in Kammarpally Forest Range of Nizamabad Forest Division of Telangana State Hippocratic J. Unani Med., 11(4):113-129.

Ibn al-Baitar (2003). Al-Jame-al-Mufradat al-Advia wal Aghzia, 1st published in 1874, CCRUM, New Delhi, Vol. I-IV (Urdu trans.).

Ingram, A.J.; Parbtani, A.; Clark, W.F.; Spanner, E.; Huff, M.W.; Philbrick, D.J. and Holub, B.J. (1995). Effects of flaxseed and flax oil diets in a rat5/6 renal ablation model. Am J Kidney Dis., 25(2):320-329. doi: 10.1016/0272-6386(95)90015-2. PMID: 7847360. 
Ishikawa, T.; Sega, Y. and Kitajima, J. (2001). Water-soluble constituents of ajowan. Chem. Pharm. Bull. (Tokyo)., 49(7):840-844. DOI: $10.1248 / \mathrm{cpb} .49 .840$.

Jadid, N.; Kurniawan, E.; Himayani, C.E.S.; Andriyani,; Prasetyowati, I.;, Purwani, K.I.; Muslihatin, W.; Hidayati, D. and Tjahjaningrum,. I.T.D. (2020). An ethnobotanical study of medicinal plants used by the Tengger tribe in Ngadisari village, Indonesia. Plos One, 15(7):1-16. DOI: 10.1371/journal.pone. 0235886

Jan, H. A.; Jan, S.; Bussmann, R. W.; Ahmad, L.; Wali, S. and Ahmad, N. (2020). Ethnomedicinal survey of the plants used for gynecological disorders by the indigenous community of District Buner, Pakistan. Ethnobotany Res Appl, 19:1-18. Retrieved from https:/ /ethnobotanyjournal.org/index.php/era/article/view/1797.

Jan, S.A.; Shinwari, Z.K.; Zeb, A.; Khalil, A.T. and Shah, S.H. (2015) Ethnobotany and Research Trends in Trachyspermum ammi L. (Ajowan); A Popular Folklore Remedy. American-Eurasian Journal of Agricultural and Environmental Sciences, 15(1):68-73,

Jaric, S.; Mitroviæ, M.; Djurdjeviæ, L.; Kostiæ, O.; Gajiæ, G.; Pavloviæ, D. and Pavloviæ, P. (2011). Phytotherapy in medieval Serbian medicine according to the pharmacological manuscripts of the Chilandar Medical Codex (15-16th centuries). J. Ethnopharmacol., 137(1):601-619.

Jaric, S.; Popoviæ, Z.; Macukanoviæ-Jociæ, M.; Djurdjeviæ, L.; Mijatoviæ, M.; Karadziæ, B.; Mitroviæ, M. and Pavloviæ, P. (2007). An ethnobotanical study on the usage of wild medicinal herbs from Kopaonik Mountain (Central Serbia). J. Ethnopharmacol., 111(1):160-175. DOI: $10.1016 /$ j.jep.2006.11.007.

Jia, L. (2012). Cancer complementary and alternative medicine research at the US National Cancer Institute. Chin. J Integr. Med., 18:325332 .

Kabeeruddin, M. (1937). Kitabul Advia, Makhzan-al-Mufradat. Aligarh Barqi Press, New Delhi, Vol. II.

Kaileh, M.; Berghe W.V.; Boone, E.; Essawi, T. and Haegeman, G. (2007) Screening of indigenous Palestinian medicinal plants for potential antiinflammatory and cytotoxic activity. J. Ethnopharmacol., 113(3):510-516. DOI: 10.1016/j.jep.2007.07.008.

Kaithwas, G. and Majumdar, D.K. (2010). Evaluation of antiulcer and antisecretory potential of Linum usitatissimum fixed oil and possible mechanism of action. Inflammopharmacology, 18:137145

Kaithwas, G.; Mukherjee, A, Chaurasia, A.K. and Majumdar, DK. (2011). Antiinflammatory, analgesic and antipyretic activities of Linum usitatissimum L. (flaxseed/linseed) fixed oil. Indian J. Exp. Biol., 49:932-938.

Karakaya, S.; Polat, A.; Aksakal, O.; Sümbüllü, Y.Z. and Ýncekara, U. (2020). Ethnobotanical study of medicinal plants in Aziziye district (Erzurum, Turkey). Turk. J. Pharm. Sci., 17(2):211-220.

Kaur, G.J. and Arora, D.S. (2009). Antibacterial and phytochemical screening of Anethum graveolens, Foeniculum vulgare and Trachyspermum ammi. BMC Complement, Altern, Med., 9, Article number: 30.

Kaur, N.; Kishore, L. and Singh, R. (2017). Therapeutic effect of Linum usitatissimum L. in STZ-nicotinamide induced diabetic nephropathy via inhibition of AGE's and oxidative stress. J. Food. Sci Technol., 54:408-421.

Kaur, T.; Bijarnia, R.K.; Singla, S.K. and Tandon, C. (2009). Purification and characterization of an anticalcifying protein from the seeds of Trachyspermum ammi (L.). Protein. Pept. Lett., 16(2):173-181. DOI: $10.2174 / 092986609787316252$.
Kavoosi, G.; Tafsiry, A.; Ebdam. A.A. and Rowshan, V. (2013). Evaluation of antioxidant and antimicrobial activities of essential oils from Carum copticum seed and Ferula assafoetida latex. J. Food Sci., 78(2):356-361. DOI: 10.1111/1750-3841.12020.

Keys, J.D. (1985). Chinese Herbs, Their Botany, Chemistry and Pharmacodynamics. Rutland, Vermont, Charles E. Tuttle Co., Tokyo, Japan.

Khan, A. (2006). Avicenna (Ibn Sina): Muslim physician and philosopher of the eleventh century (Great Muslim Philosophers and Scientists of the Middle Ages). The Rosen Publishing Group, New York, USA.

Khan, R.; Zakir, M.; Afaq, S.H.; Latif, A. and Khan, A.U. (2010). Activity of solvent extracts of Prosopis spicigera, Zingiber officinale and Trachyspermum ammi against multidrug resistant bacterial and fungal strains. J. Infect. Dev. Ctries., 4(5):292-300. DOI: $10.3855 /$ jidc. 621 .

Khan, S.; Shameem, I.; Sahibole, S. and Aafreen Siddiqui, A. (2016) Trachyspermum ammi: Ancient unani medicine for modern cure, a review of potential therapeutic applications. World J. Pharm. Res., 5(12): 169-178.

Khan, Z.S. (2013). Ethnobotanical survey of Thane district. Ann. Pharm. Pharma. Sci.. 4(1-2):22-25.

Khare, B. (2017). A Preliminary Ethnobotanical Survey of Sehore District of Madhya Pradesh. International Journal of ResearchGranthaalayah, 5(6):58-62.

Khare, C.P. (2004). Indian Herbal Remedies Rational Western Therapy, Ayurvedic and Other Traditional Usage, Botany. Springer-Verlag, Berlin, Heidelberg.

Khory, R.N. and Katrak, N.N. (1984). Materia Medica of India and Their Therapeutics. Neeraj Publishing House New Delhi.

Kianifar, J.; Azadbakht, M.; Azadbakht, M. and Davoodi, A. (2019). Ethnobotanical study of medicinal plants used in skin diseases in the area Alamut-Qazvin, Iran. Journal of Medicinal Plants, 18 (72):121-132.

Kirtikar, KR, Basu BD. (1996) Indian Medicinal Plants, Vols. I-IV. Allahabad, New Delhi, Dehradun: Indian Council of Medical Research (ICMR).

Kishore, R.N.; Anjaneyulu, N.; Ganesh, M.N. and Sravya, N. (2012). Evaluation of anxiolytic activity of ethanolic extract of Foeniculum vulgare in mice model. International Journal of Pharmacy and Pharmaceutical Sciences, 4(3):584-586.

Kumar, B. (2019). Ethnobotanical investigation of medicinal plants used by rural communities of district Chatra, Jharkhand, India." IOSR Journal of Biotechnology and Biochemistry, 5(6):34-49.

Kumar, G. and Chander, H. (2017). Documentation of indigenous agricultural Implements, practices and other conservation techniques in subtropical climatic zone of Shivalik Hills, North Western Himalaya. J. Biol. Chem. Chron., 3(2):15-23.

Kumar, M.; Paul, Y. and Anand, V. K. (2009). An ethnobotanical study of medicinal plants used by the locals in Kishtwar, Jammu and Kashmir, India. Ethnobotanical Leaflets, 13(10)1240-1256.

Kunzemann, J. and Herrmann, K. (1977). Isolation and identification of flavon(ol)-O-glycosides in caraway (Carum carvi L.), fennel (Foeniculum vulgare Mill.), anise (Pimpinella anisum L.), and coriander (Coriandrum sativum L.), and of flavon-C-glycosides in anise-I. Phenolics of spices. Z. Lebensm. Unters. Forsch., 164 (3):194-200 
Lixandru, B,E.; Drãcea, N.O.; Dragomirescu, C.C.; Drãgulescu, E.C.; Coldea, I.L.; Anton, L.; Dobre, E.; Rovinaru, C. and Codipã, I. (2010). Antimicrobial activity of plant essential oils against bacterial and fungal species involved in food poisoning and/or food decay. Roum. Arch. Microbiol. Immunol., 69(4):224-230.

Lone F.A.; Lone, S.; Aziz, M.A. and Malla, F.A. (2012). Ethnobotanical studies in the tribal areas of district Kupwara, Kashmir, India. Int. J. Pharm. Bio. Sci., 3(4):399-411.

Malik. K.; Ahmad, M.; Bussmann, R.W.; Tariq, A.; Ullah, R.; Alqahtani, A.S.; Shahat ,A.A.; Rashid, N.; Zafar, M. ; Sultana, S. and Shah, S.N. (2018). Ethnobotany of anti-hypertensive plants used in Northern Pakistan. Front. Pharmacol., 9:1-19. Doi: 10.3389/fphar.2018. 00789.

Malini, T.; Vanithakumari, G.; Megala, N.; Anusya, S.; Devi, K. and Elango, V. (1985). Effect of Foeniculum vulgare Mill. seed extract on the genital organs of male and female rats. Indian. J. Physiol. Pharmacol., 29(1):21-26.

Mathew, N.; Misra-Bhattacharya, S.; Perumal, V. and Muthuswamy, K. (2008) Antifilarial lead molecules isolated from Trachyspermum ammi. Molecules. 11; 13(9):2156-68. doi: 10.3390/molecules13092156. PMID: 18830147.

Matsumoto, T.; Shishido, A.; Morita, H.; Itokawa, H. and Takeya, K. (2001). Cyclolinopeptides F-I, cyclic peptides from linseed. Phytochemistry, 57:251-260.

Mautone, M.; Martino, L.D. and Feo, V.D. (2019). Ethnobotanical research in Cava de' Tirreni area, Southern Italy. J. Ethnobiology Ethnomedicine, 15:1-21. https://doi.org/10.1186/s13002-0190330-3.

Mayaud, L.; Carricajo, A.; Zhiri, A. and Aubert, G. (2008). Comparison of bacteriostatic and bactericidal activity of 13 essential oils against strains with varying sensitivity to antibiotics. Lett. Appl. Microbiol., 47(3):167-73. DOI: 10.1111/j.1472-765X.2008. 02406.x.

Miguel, M.G.; Cruz, C.; Faleiro, L.; Simões, M.T.; Figueiredo, A.C.; Barroso, J.G and Pedro, L.G. (2010). Foeniculum vulgare essential oils: Chemical composition, antioxidant and antimicrobial activities. Nat. Prod. Commun., 5(2):319-328.

Mitalaya, K.D.; B hatt, D.C.; Patel, N.K. and Didia, S.K. (2003). Herbal remedies used for hair disorders by tribals and rural folk in Gujarat. Indian J. Trad. Knowledge., 2(4):389-392.

Mohamadi, N.; Sharififar, F.; Koohpayeh, A. and Daneshpajouh, M. (2015). Traditional and ethnobotanical uses of medicinal plants by ancient populations in Khabr and Rouchon of Iran. J. App. Pharm. Sci., 5 (11):101-107.

Moazzami, F., S.; Ghorbani, A., Ajani, Y., Sadr, M. and Mozaffarian, V (2018). Ethnobotanical applications and their correspondence with phylogeny in Apiaceae-Apioideae. Res. J. Pharmacogn., 5(3):7997. doi: $10.22127 /$ rjp.2018.64880.

Mostafa, E. K.; Dandani, Y.; Chaachouay, N.; Hmouni, D. and Garrido, G. (2021). Ethnobotanical study of plants used for medicinal, cosmetic, and food purposes in the region of Moulay Yacoub, Northeast of Morocco. J. Pharm. Pharmacogn. Res., 10(1):13-29.

Nadkarni, A.K. (1954). Indian Materia Medica. 3rd ed. Bombay: Popular Book Depot and Dhootapapeshwar Parakashan Ltd., Panval, India.

Najem, M.; Harouak, H.; Ibijbijen, J. and Nassiri, L. (2020). Oral disorders and ethnobotanical treatments: A field study in the central Middle Atlas (Morocco). Heliyon., 6(8) 1-11. https://doi.org/10.1016/ j.heliyon.2020.e04707.
Naran, R.; Chen, G. and Carpita, N.C. (2008). Novel rhamnogalacturonan I and arabinoxy lan polysaccharides of flaxseed mucilage. Plant Physiol., 148:132-141.

Newairy, A.S. and Abdou, H.M. (2009). Protective role of flax lignans against lead acetate induced oxidative damage and hyperlipidemia in rats. Food Chem Toxicol., 47:813-8.

Nickavar, B. and Abolhasani, F.A. (2009). Screening of antioxidant properties of seven Umbelliferae fruits from Iran. Pak. J. Pharm., 22(1):30-35. PMID: 19168417.

Noweir, M.H.; el-Sadik, Y.M.; el-Dakhakhny,A.A. and Osman, H.A. (1975). Dust exposure in manual flax processing in Egypt. Br. J. Ind. Med., 32(2):147-154. DOI: 10.1136/oem.32.2.147. PMID: 1131341

Oliveira, S. G. D.; Moura, F. R. R. D.; Demarco, F. F.; Nascente, P. D. S.; Pino, F.A. B.D. and Lund, R.G. (2012). An ethnomedicinal survey on phytotherapy with professionals and patients from basic care units in the Brazilian Unified Health System. Journal of Ethnopharmacology, 140(2):428-437.

Ostad, S. N.; Soodi, M.; Shariffzadeh, M.; Khorshidi, N. and Marzban, H. (2001). The effect of fennel essential oil on uterine contraction as a model for dysmenorrhea, pharmacology and toxicology study. J. Ethnopharmacol., 76(3):299-304.

Ozbek, H.; Uðrap, S.; Dülger, H.; B ayram, I.; Tuncer, I.; Oztürk, G. and Oztürk, A. (2003). Hepatoprotective effect of Foeniculum vulgare essential oil. Fitoterapia, 74(3):317-319

Pai, M.B.; Prashant, G.M.; Murlikrishna, K.S.; Shivakumar, K.M. and Chandu, G.N. (2010). Antifungal efficacy of Punica granatum, Acacia nilotica, Cuminum cyminum and Foeniculum vulgare on Candida albicans: an in vitro study. Indian. J. Dent. Res., 21(3):334-336. DOI: $10.4103 / 0970-9290.70792$.

Pande, N. and Joshi, A. (2015). Paediatric ethnobotany of the Boxa Tribe of Tarai and Bhabar Region of Uttarakhand, India. Int. J. Scie. Res., 4(4):24-26.

Parejo, I.; Jauregui, O.; Sánchez-Rabaneda, F.; Viladomat, F.; Bastida, J. and Codina, C. (2004). Separation and characterization of phenolic compounds in fennel (Foeniculum vulgare) using liquid chromatography-negative electrospray ionization tandem mass spectrometry. J. Agric. Food. Chem., 52(12):3679-3687. Doi: $10.1021 /$ jf030813h.

Park, J.B. and Velasquez, M.T. (2012). Potential effects of lignan-enriched flaxseed powder on body weight, isceral fat, lipid profile, and blood pressure in rats. Fitoterapia., 83:941-946.

Pieroni, A. and Giust. M.E. (2009). Alpine ethnobotany in Italy: Traditional knowledge of gastronomic and medicinal plants among the Occitans of the upper Varaita valley, Piedmont. J. Ethnobiol. Ethnomed., 5:32. DOI:10.1186/1746-4269-5-32.

Prasad, K. (2005). Hypocholesterolemic and antiatherosclerotic effect of flax lignin complex isolated from flaxseed. Atherosclerosis, 179:269-275.

Prasad, K. (2007). A study on regression of hypercholesterolemic atherosclerosis in rabbits by flax lignan complex. J. Cardiovasc. Pharmacol. Ther., 12:304-313.

Prasad, K. (2008). Regression of hypercholesterolemic atherosclerosis in rabbits by secoisolariciresinol diglucoside isolated from flaxseed. Atherosclerosis, 197:34-42.

Prasad, K. (2009). Flax lignan complex slows down the progression of atherosclerosis in hyperlipidemic rabbits. J. Cardiovasc. Pharmacol. Ther., 14:38-48. 
Rajesha, J.; Murthy, K.N.; Kumar, M. K.; Madhusudhan, B. and Ravishankar G.A. (2006). Antioxidant potentials of flaxseed by in vivo model. J. Agric. Food Chem., 54:3794-3799.

Rasul, A.; Akhtar, N.; Khan, B.A.; Mahmood, T.; Zaman, S. U. and Khan, H. M. S. (2012). Formulation development of a cream containing fennel extract: In vivo evaluation for antiaginget effects. Pharmazie, 67 (1):54-58.

Reddy, K. N.; Reddy, C.S. and Trimurthulu, G. (2006). Ethnobotanical Survey on respiratory disorders in eastern Ghats of Andhra Pradesh, India. Ethnobotanical Leaflets, 10:139-148.

Rehman, M.N. and Ahmad, M. (2018). Dietary patterns for the reduction of obesity using medicinal plants in northern Pakistan. J. Obes Weight Loss Ther., 8(1):364. DOI: 10.4172/2165-7904.1000 3648:364.

Renu, N.; Kaithwas, G.; Ramteke P.W. and Saraf, S.A. (2012). Effect of Linum usitatissimum linseed/flaxseed) fixed oil on experimental esophagitis in albino rats. Acta. Gastroenterol. Belg., 75:331-335.

Rezvani, M.E.; Roohbakhsh, A.; Mosaddegh, M.H.; Esmailidehaj, M.; Khaloobagheri, F. and Esmaeili, H. (2011). Anticonvulsant and depressant effects of aqueous extracts of Carum copticum seeds in male rats. Epilepsy. Behav., 22(2):220-225. DOI: 10.1016/j.yebeh.2011. 07.017 .

Rickard, S.E.; Yuan, Y.V.; and Thompson L.U. (1999). Dose effects of flaxseed and its lignan on $\mathrm{N}$-methyl-N-nitrosourea-induced mammary tumorigen esis in rats. Nutr. Cancer., 35:50-57.

Rickard, S.E.; Yuan, Y.V.; and Thompson L.U. (2000). Plasma insulin-like growth factor I levels in rats are reduced by dietary supplementation of flaxseed or its lignan secoisolariciresinol diglycoside. Cancer Lett., 161:47-55.

Rodriguez-Leyva, D.; Dupasquier, C.M.; McCullough, R. and Pierce, G.N. (2010), The cardiovascular effects of flaxseed and its omega-3 fatty acid, alpha linolenic acid. Can. J. Cardiol., 26:489-496.

Saha, J.C. and Kasinathan S. (1961) Ecbolic properties of Indian medicinal plants. II. Indian J. Med. Res., 49:1094-1098.

Sankaran, D.; Bankovic-Calic, N.; Peng, C.Y.; Ogborn, M.R. and Aukema, H.M. (2006). Dietary flax oil during pregnancy and lactation retards disease progression in rat offspring with inherited kidney disease. Pediatr Res., 60(6):729-733. DOI: 10.1203/01.pdr.0000245912. 78078.d5.

Sankaran, D.; Bankovic-Calic, N.; Cahill, L.; Yu-Chen Peng, C.; Ogborn, M.R. and Aukema, H.M. (2007). Late dietary intervention limits benefits of soy protein or flax oil in experimental polycystic kidney disease. Nephron Exp Nephrol., 106:e122-128. DOI:10.1159/000104836

Savo, V.; Giulia, C.; Maria, G. P. and David R. (2011). Folk phytotherapy of the Amalfi Coast (Campania, Southern Italy). Journal of Ethnopharmacology, 135(2):376-392.

Schmidt, T.J.; Klaes, M. and Sendker, J. (2012). Lignans in seeds of Linum species. Phytochemistry, 82:89-99.

Shalby, A.B.; Hamza, A.H. and Ahmed, H.H. (2012). New insights on the anti-inflammatory effect of some Egyptian plants against renal dysfunction induced by cyclosporine. Eur. Rev .Med. Pharmacol. Sci., 16:455-461

Sharma, N. and Kumar, G. (2015). Exploration of some ethnomedicinal plants used by natives of Hamirpur district in Himachal Pradesh, India. Asian Agri-History, 19(2):95-104.
Sharma, S.D.; Sahu, K.; Chandrol, G.K.; Jain, P.K. and Sharma,V. (2016). Ethnobotanical survey of five villages of Durg district of Chhattisgarh, (India). Int. J. Adv. Res. Biol. Sci., 3(10):104-110.

Shende, J. J.; Rajurkar, B. M.; Mhaiskar, M. N. and Dala, L. P. (2014). Ethnobotanical Studies of Samudrapur Tahsil of Wardha District. Journal of Pharmacy and Biological Sciences, 9(6):16-23.

Singh, A. and Singh, P.K. (2009). An ethnobotanical study of medicinal plants in Chandauli District of Uttar Pradesh, India. J. Ethnopharmacol., 121:324-329, 10.1016/j.jep.2008.10.018.

Sonar, P.K.; Singh, R. and Saraf, S.K. (2016). Phytochemical, chromatographic and spectroscopic investigation of Carum copticum seeds and their potential as immunomodulatory agents. Pharm. Biol., 54(3):494-502. DOI: 10.3109/13880209.2015. 1050116.

Srivastava, K.C. (1988). Extract of a spice-omum (Trachyspermum ammi)-shows antiaggregatory effects and alters arachidonic acid metabolism in human platelets. Prostaglandins. Leukot. Essent. Fatty Acids, 33(1):1-6. DOI:10.1016/0952-3278(88)90115-9.

Tanira, M. O.; Shah, A. H.; Mohsin, A. A.; Ageel, M. and Qureshi, S. (1996). Pharmacological and toxicological investigations on Foeniculum vulgare dried fruit extract in experimental animals. Phytotherapy Research, 10(1):33-36.

Telci, I.; Demirtas, I. and Sahin, A. (2009). Variation in plant properties and essential oil composition of sweet fennel (Foeniculum vulgare Mill.) fruits during stages of maturity," Industrial Crops and Products, 30(1):126-130.

Tene, V.; Malagon, O.; Finzi, P. V.; Vidari, G.; Armijos, C. and Zaragoza, T. (2007). An ethnobotanical survey of medicinal plants used in Loja and Zamora-Chinchipe, Ecuador," J Ethnopharmacol, 111(1):63-81.

Tognolini, M.; Ballabeni, V.; Bertoni, S.; Bruni, R.; Impicciatore, M. and Barocelli, E. (2007). Protective effect of Foeniculum vulgare essential oil and anethole in an experimental model of thrombosis. Pharmacol. Res., 56(3):254-260. DOI: 10.1016/j.phrs.2007. 07.002 .

Tomaz Pacheco, J.; Beltrame Daleprame, J. and Teles Boaventura, G. (2011). Impact of dietary flaxseed (Linum usitatissimum) supplementation on biochemicalprofile in healthy rats. Nutr Hosp., 26:798-802.

Tou, J.C.; Chen, J. N. and Thompson, L.U. (1998). Flaxseed and its lignan precursor, secoisolariciresinol diglycoside, affect pregnancy outcome and reproduc tive development in rats. J. Nutr., 128:18611868.

Tou, J.C.; Chen, J. N. and Thompson, L.U. (1999). Dose, timing, and duration of flaxseed exposure affect reproductive indices and sex hormone levels in rats. J. Toxicol. Environ. Health A., 56:555-570.

Ullah, Z.; Rashid, A.; Bashriruddin; Shah, M.; Ali, M.; Gul, H. and Khan, A. (2018). Ethnobotanical studies of medicinal plants of Malakand district. FUUAST J. Biol., 8(1):161-167.

Vasudevan, K.; Vembar, S.; Veeraraghavan, K. and Haranath, P.S. (2000). Influence of intragastric perfusion of aqueous spice extracts on acid secretion in anesthetized albino rats. Indian. J. Gastroenterol., 19:53-56.

Wang, H.; Wang J.; Qiu, C.; Ye, Y.; Guo, X.; Chen, G.; Li T.; Wang, Y.; Fu, X. and Liu, RH. (2017). Comparison of phytochemical profiles and health benefits in fiber and oil flaxseeds (Linum usitatissimum L.). Food Chem., 214:227-233. 
Xu, J.; Zhou, X.; Chen, C.; Deng, Q.; Huang, Q.; Yang, J.; Yang, N. and Huang, F. ( 2012). Laxative effects of partially defatted flaxseed meal on normal and experimental constipated mice. BMC Complement Altern Med., 12:14. DOI:10.1186/1472-6882-12-14. PMID: 22400899.

Yadav, S.S.; Bhukal, R.K.; Bhandoria, M.S.; Ganie, S.A.; Gulia S.K. and Raghav T.B.S. (2014). Ethnoveterinary medicinal plants of Tosham Block of district Bhiwani (Haryana) India. J. Applied Pharma. Sci., 4 (06):40-48.

Yan, L. and Yee, J.A.;Li, D. McGuire, M.H. and Thompson, L. U. (1998). Dietary flaxseed supplementation and experimental metastasis of melanoma cells in mice. Cancer Lett., 124:181-186. DOI:10.1016/ s0304-3835(97)00470-9. PMID: 9500208.

Yang, I.J.; Lee, D.U. and Shin, H.M. (2015). Anti-inflammatory and antioxidant effects of coumarins isolated from Foeniculum vulgare in lipopolysaccharide-stimulated macrophages and 12-O-tetrade canoylphorbol-13-acetate-stimulated mice. Immunopharmacol. Immunotoxicol., 37(3):308-317.

Yoder, L.H. (2005). Let's talk cancer prevention. Med. Surg. Nursing., 14:195-198.
Zahin, M.; Ahmad, I. and Aqil, F. (2010). Antioxidant and antimutagenic activity of Carum copticum fruit extracts. Toxicol. In vitro., 24(4):1243-1249. DOI: 10.1016/j.tiv.2010.02.004.

Zaidi, S.F.; Muhammad, J.S.; Shahryar, S.; Usmanghani, K.; Gilani, A.H.; Jafri, W. and Sugiyama, T. (2012). Antiinflammatory and cytoprotective effects of selected Pakistani medicinal plants in Helicobacter pylori-infected gastric epithelial cells. J. Ethnopharmacol., 141(1):403-410. doi: 10.1016/j.jep.2012.03.001.

Zarshenas, M.M.; Samani, S.M.; Petramfar, P. and Moein, M. (2014). Analysis of the essential oil components from different Carum copticum L. Samples from Iran. Pharmacognosy Research, 6(1):62-66.

Zeng, H.; Chen, X. and Liang, J. (2015). In vitro antifungal activity and mechanism of essential oil from fennel (Foeniculum vulgare L.) on dermatophyte species. J. Med. Microbiol., 64:93-103.

Zoubiri, S.; Baaliouamer, A.; Seba, N. and Chamouni, N. (2010). Chemical composition and larvicidal activity of Algerian Foeniculum vulgare seed essential oil. Arabian Journal of Chemistry, 7(4): 480-485.

Mohd. Kashif Husain (2021). Herbs that heal: Relevance of traditional natural remedies in promotion of health. Ann. Phytomed., 10(2):4-21. http://dx.doi.org/10.21276/ap.2021.10.2.2 